\title{
ZOOMING OUT: \\ THE TRADE EFFECT OF THE EURO IN HistoricAl PERSPECTIVE
}

\author{
HELGE BERGER \\ VOLKER NITSCH
}

\author{
CESIFO WORKING PAPER NO. 1435 \\ CATEGory 6: Monetary Policy and InTERnational FinanCe \\ MARCH 2005
}

Presented at CESifo Area Conference on Global ECONOMY,

DECEMBER 2004

An electronic version of the paper may be downloaded

- from the SSRN website:

http://SSRN.com/abstract $=700661$

- from the CESifo website: www.CESifo.de 


\title{
ZOOMING OUT: THE TRADE EFFECT OF THE EURO IN HistORICAL PERSPECTIVE
}

\begin{abstract}
In 1999, eleven European countries formed the Economic and Monetary Union (EMU); they abandoned their national currencies and adopted a new common currency, the euro. Several recent papers argue that the introduction of the euro has led (by itself) to a sizable and statistically significant increase in trade between the member countries of EMU. In this paper, we put the trade effect of the euro in historical perspective. We argue that the creation of the EMU was a continuation (or culmination) of a series of previous policy changes that have led over the last five decades to greater economic integration among the countries that now constitute EMU. Using a data set that includes 22 industrial countries from 1948 to 2003, we find strong evidence of a gradual increase in trade intensity between European countries. Once we control for this trend in trade integration, the euro's impact on trade disappears. Moreover, a significant part of the trend in European trade integration is explained by measurable policy changes.
\end{abstract}

JEL Code: F02, F15, F33.

Keywords: monetary union, currency, euro, trade, European integration.

Helge Berger
Free University Berlin
Department of Economics
Boltzmannstr. 20
14195 Berlin
Germany
hberger@wiwiss.fu-berlin.de

Helge Berger

Free University Berlin

Boltzmannstr. 20

Berlin

hberger@wiwiss.fu-berlin.de 


\section{Introduction}

On January 1, 1999, eleven countries formed the European Economic and Monetary Union (EMU); they formally abandoned their national currencies and adopted a new currency, the euro. ${ }^{1}$ A number of recent papers argue that the formation of the EMU has had a sizable effect on the member countries' pattern of international trade. Micco, Stein, and Ordoñez (2003, henceforth MSO), for instance, find that for pairs of countries that have adopted the euro, trade has increased by about 4-16 percent. Other papers, including Baldwin, Skudelny, and Taglioni (2005), Barr, Breedon, and Miles (2003), Bun and Klaassen (2002), De Nardis and Vicarelli (2003), De Sousa and Lochard (2004), Faruqee (2004), and Flam and Nordström (2003), report broadly similar, and often even larger, estimates.

While much of this work should be taken with caution (given that, at this early stage, only a few years of data from the EMU period are available $)^{2}$, the finding that the introduction of the euro has a positive and significant effect on intra-EMU trade has attracted considerable attention for at least two reasons. For one thing, the result has important policy implications. If a common currency immediately boosts trade even among highly integrated economies, currency unions become more attractive. As a result, countries that are currently considering joining EMU may opt for an early adoption of the euro.

A more general implication is that a positive trade effect of the euro - even if initially moderate in magnitude - would appear to provide empirical support for Andrew Rose's (2000) finding that establishing a common currency significantly increases trade among union members. ${ }^{3}$ Rose's finding was met with great skepticism. Critics noted, for instance, that the conclusions were based on a sample of currency union members that mainly consists of small, poor and dependent territories and therefore might not apply to other economies. ${ }^{4}$ The formation of the EMU allows addressing at least some of the objections: it presents one of

\footnotetext{
${ }^{1}$ The countries are: Austria, Belgium, Finland, France, Germany, Ireland, Italy, Luxembourg, Netherlands, Portugal and Spain. As twelfth member country, Greece joined EMU on January 1, 2001. All of our empirical results refer to the original eleven EMU members (with joint data for Belgium and Luxembourg); we get qualitatively similar results when we use EMU-12 instead.

${ }^{2}$ The sample period that is analyzed in these papers typically extends through the end of 2002. At that time, EMU had been in existence for four years. However, since the euro was not introduced as a physical currency before January 1,2002 , the sample period often covers only a single year of data from when the new currency was actually in circulation.

${ }^{3}$ Previous results suggest that the trade effect of currency union entries/exits may be subject to extremely long lags. Glick and Rose (2002) estimate that it will take about three decades after a change in the currency regime for trade to double.

${ }^{4}$ Persson (2001) even argues that Rose's empirical specification is inappropriate since countries that belong to currency unions are systematically different from the rest of the sample.
} 
those rare "natural experiments" that permits analyzing the impact of the introduction of a common currency on trade between large and independent nations. ${ }^{5}$

In this paper, we take a fresh look at the evidence on the euro's effect on trade. In particular, we argue that the potential trade-creating effects of the EMU must be viewed - and analyzed - in the proper historical perspective. Rather than focusing on the formation of a monetary union as an isolated event, we emphasize that the creation of the EMU was a continuation, or perhaps a culmination, of an integration process that started almost half a century ago. ${ }^{6}$ In fact, this process may go back (at least) as far as the Marshall plan of 1948, which, according to Berger and Ritschl (1995), helped to reestablish the traditional European division of labor in trade. The 1950s saw efforts to harmonize tariffs, regulations, and economic policies across European countries, leading up to the Treaty of Rome in 1957. After the removal of internal trade barriers, the integration process continued, eventually encompassing European monetary cooperation (after the end of the Bretton Woods system), a gradual increase in EU membership (in the 1970s and 1980s), and the introduction of the single market framework (in 1987). Since all this set the table for the Maastricht Treaty of 1991 and, thus, ultimately the formation of the EMU, the question of interest to us is: What has been the euro's impact on trade above and beyond the impact of previous and ongoing steps toward economic integration in Europe?

Taking a long-run view of European integration, we find that the introduction of the euro has almost no measurable effect on trade. In particular, the incremental trade effect of the euro is reduced once elements of European economic integration, such as trade liberalization, economic harmonization, and low exchange rate volatility, are taken into account. More importantly, there is strong evidence for a gradual increase (rather than a one-time jump) in trade intensity between countries that later join the EMU over a period of more than a half century. As soon as we control for this long-term trend, the introduction of the euro has no additional effect on trade. These results are robust across a number of model specifications and alternative data sets.

The remainder of the paper is organized as follows. In section II, we briefly review the existing evidence of the euro's effect on trade. Section III describes our estimation

\footnotetext{
${ }^{5}$ Other episodes of currency union formation and entry in the post-war period are analyzed in Nitsch (2005).

${ }^{6}$ Faruqee (2004, p. 4) makes a similar point, arguing that EMU is best viewed as an "ongoing process that, in many ways, preceded the euro".
} 
methodology and the data, followed by a presentation of our benchmark results on the evolution of trade between current EMU members over a period of more than 50 years. Section V explores some determinants of growing intra-EMU trade, and section VI provides a short conclusion.

\section{Zooming In: Some Open Issues}

Previous findings of a significant trade-enhancing effect of EMU, although generally consistent with Rose's (2000, 2004) observation that common currencies promote trade, invite a more detailed examination for a number of reasons. We focus here on results reported in MSO; other studies often present (qualitatively) similar results. ${ }^{7}$

A first notable observation from these papers is that the estimated trade effect of the euro appears to be surprisingly large relative to the trade effect of membership in the European Union (EU). According to MSO's benchmark cross-country regressions (reported in their Table 1), the point estimate of EMU membership on trade is 0.20 , while the estimated coefficient of EU membership on trade is only marginally larger, at 0.27 . These results imply that the adoption of the euro has almost the same impact on trade as the removal of trade barriers and the creation of a single market (i.e., further harmonization and integration) in the European Union. ${ }^{8}$ Given the much shorter history of EMU and the large degree of monetary integration that was already achieved before the adoption of the euro (with low exchange rate volatility between countries that later join the EMU), this is a remarkable finding inviting further study.

Another interesting empirical observation is that trade between EMU members was obviously already disproportionately large in 1998, i.e., one year before the formation of the monetary union (and the irrevocable fixing of exchange rates); see Table 2 in MSO. ${ }^{9}$ The

\footnotetext{
${ }^{7}$ Gomes et al. (2004) discuss some of these points in more detail; they also provide an excellent review of the related literature.

${ }^{8}$ The total impact of EU membership is obtained by adding the coefficient of EU membership, the coefficient of the EU Trend multiplied by the mean of the trend, and the coefficient of membership in a Free Trade Arrangement; see footnote 2 in MSO. The coefficients imply that trade between EMU members is estimated to be 22 percent (=exp[0.20]-1) higher than the rest of the sample after 1999, while the trade-increasing effect of EU membership is estimated at 31 percent (=exp[0.27]-1).

${ }^{9}$ It should also be noted that, in principle, several dates could be identified as important for the introduction of the euro, each of which could be associated with a significant increase in trade. These dates include the signing of the Maastricht treaty in February 1992, the fixing of the final date for the beginning of the currency union at
} 
decision about the final set of participating countries, however, was only made in early/mid1998 and even then some uncertainties remained. For instance, the ultimate conversion rates were not specified until the very end of the convergence process, making a strong anticipation effect less likely. ${ }^{10}$ These difficulties in dating the exact beginning of the EMU point towards other - somewhat more continuous - dimensions of the European integration process that are often neglected.

Indeed, reviewing the results on the evolution of trade intensity between EMU countries in MSO's Table 2 more generally, there appears to be gradual increase in trade integration over the (full) period (from 1992 through 2002) that is analyzed by MSO; the results indicate a surprisingly steady rise in the estimated intra-EMU trade intensities. The yearly EMU coefficients increase from a low of -0.02 (with a standard error of 0.03) in 1993 to $0.04(0.03)$ in 1997 and, after rising both in terms of size and significance in 1998, the coefficients continue to grow over the EMU period from $0.12(0.03)$ in 1999 to $0.15(0.04)$ in 2002. ${ }^{11}$

Finally, MSO also present results on the trade effect of the euro disaggregated by country (and by country group). These estimates (reported in their Table 7) suggest that the EMU had the largest effect on trade for countries of the former Deutsche-Mark bloc. In fact, when the DM bloc is dropped from the sample, the estimated coefficient on EMU membership even becomes statistically insignificant. However, since the exchange rate links between the DM bloc countries (including the non-EMU member Denmark) were, as a rule, already tight before the adoption of a common currency, it is striking to find that the introduction of the euro had the strongest effect on these countries. This invites further investigation of country-specific elements in the European integration process.

In the following, we argue that many of these results, in particular the finding of a sizable increase in trade after the introduction of the euro, are very sensitive to the analyzed time period and the regression specification. Extending the length of the sample to cover the

the end of 1997, the actual start of the EMU on January 1, 1999, or the introduction of the euro as physical currency on January 1, 2002.

${ }^{10}$ See Flam and Nordström (2003) for an alternative view.

${ }^{11}$ To illustrate, regressing MSO's EMU coefficients for the developed country sample and the period from 1993 through 2002 on a constant and a linear time trend yields a highly significant estimate of about 0.02 and an adjusted $\mathrm{R}^{2}$ of 0.89 . 
entire post-war period and accounting for the underlying non-monetary integration dynamics within the European Union has a significant impact on estimation results.

\section{Methodology and Data}

We estimate variants of an augmented gravity model of the form:

$$
\ln \left(T_{i j t}\right)=\alpha+\sum_{\mathrm{k}=1}^{\mathrm{n}} \beta_{\mathrm{k}} \mathrm{X}_{\mathrm{ijkt}}+\gamma \mathrm{EMU}_{\mathrm{t}}\left\{+\phi_{\mathrm{ij}}+\eta_{\mathrm{t}}\right\}+\varepsilon_{\mathrm{ijt}}
$$

where $T_{i j t}$ is the volume of trade between country $i$ and $j$ at time $t$ in real US dollars; $X_{t}$ is a set of $n$ conditioning variables that are typically found to affect bilateral trade flows (such as the size of and distance between the trading partners); EMU $\mathrm{t}_{\mathrm{t}}$ is a binary variable that takes the value of one if the two countries are members of the European Monetary Union; $\left\{\phi_{\mathrm{ij}}\right\}$ and $\left\{\eta_{\mathrm{t}}\right\}$ are a comprehensive set of country pair- and time-specific fixed effects; and $\varepsilon_{\mathrm{t}}$ is a residual assumed to have standard characteristics. This set-up is standard and has been used, among others, by Rose (2000), Glick and Rose (2002) and MSO.

In early work on the common currency effect on trade, the above framework was mainly implemented in cross-section fashion; see, for instance, Rose (2000). In this specification, the data are typically pooled over time, but year dummies eliminate the timeseries variation so that the currency union dummy captures the extent to which trade between members of a currency union differs from (or, more precisely, is larger than) trade between countries using separate currencies. For illustrative purposes we reproduce MSO's benchmark regression results based on this specification in the second column of Table $1 .^{12,13}$ The point estimate of 0.19 implies that trade between EMU members is about 21 percent (=exp[0.19]-1) higher than trade between non-EMU members, holding other things constant.

\footnotetext{
${ }^{12}$ Countries in the developed country sample are: Australia, Austria, Belgium-Luxembourg, Canada, Denmark, Finland, France, Germany, Greece, Iceland, Ireland, Italy, Japan, the Netherlands, New Zealand, Norway, Portugal, Spain, Sweden, Switzerland, the United Kingdom, and the United States. The European sample is a subset of the above.

${ }^{13}$ Note that, in replicating the results, we slightly depart from MSO's regression specification. In particular, we drop two explanatory variables for which MSO report insignificant coefficients: the log product of land areas and an EU trend integration measure. Thus, for the sake of comparison, we re-estimated the gravity model with MSO's original data (taken from the Economic Policy website) instead of simply copying their original results. As shown, this hardly influences the results.
} 
For our purposes, however, the cross-sectional approach has a severe drawback. The estimated coefficient on EMU membership (as the one replicated above) is not necessarily an indication of the trade effect of the euro. In fact, it is quite plausible that the EMU countries shared a disproportionately large amount of trade already before the adoption of a common currency. Therefore, to identify the change in trade intensity after the formation of EMU, adding country-pair fixed effects might be a useful strategy. By allowing for country-pair specific intercepts that account for any particularly strong (or weak) bilateral tendency to trade, the estimator exploits the time series variation around country-pair averages and the EMU dummy captures the extent to which trade between EMU member countries differs before and after the adoption of the common currency (see Glick and Rose (2002), among others). MSO (p. 327) argue that the use of country-pair dummies "provides the cleanest possible benchmark against which to assess the euro effect on trade." 14

We follow MSO and others, and use the regression specification with a comprehensive set of country-pair fixed effects as our preferred specification. For the sake of completeness, we also continue reporting results on the cross-sectional set-up our preferred specification. ${ }^{15}$

Estimation results derived from the fixed effects regression are reported in the third column of Table 1; results from the preferred specification are presented in shaded columns. As expected, the coefficient on the EMU dummy falls considerably, suggesting that countries that later joined EMU had indeed strong trade relations already before the formation of the monetary union. Nonetheless, the coefficient on EMU membership remains positive and statistically highly significant. The estimate of about 0.05 implies that the adoption of the euro has increased trade between EMU members by about 5 percent (=exp[0.05]-1). Restricting the sample to European countries yields broadly similar results (reported in panel b of Table 1).

In the remaining columns of Table 1, we seek to replicate MSO's results using an updated data set that incorporates the most recent data revisions and extends the sample period to 2003. The exercise carefully follows MSO's original approach, using the same data sources and data definitions. ${ }^{16}$

\footnotetext{
${ }^{14}$ Klein and Shambaugh (2004) provide a more detailed discussion of the various estimation techniques.

${ }^{15}$ Parenthetically, we note that, in principle, it is possible to combine both approaches by adding a separate dummy variable to the cross-country set-up; this variable takes the value of one for the whole sample period if the two countries are - or eventually later become - EMU members (i.e., adding a pooled EMU country-pair fixed effect).

${ }^{16}$ The data set is described in more detail in Appendix 1.
} 
Table 1: The trade effect of the euro - the short run view

a) Developed countries

\begin{tabular}{|c|c|c|c|c|c|c|}
\hline Data & MSO & $\mathrm{MSO}$ & Updated & Updated & Updated & Updated \\
\hline Period & $1992-2002$ & $1992-2002$ & $1992-2002$ & $1992-2002$ & $1992-2003$ & $1992-2003$ \\
\hline EMU2 & $\begin{array}{c}0.188 * * \\
(0.038)\end{array}$ & $\begin{array}{l}0.045 * * \\
(0.014)\end{array}$ & $\begin{array}{l}0.306^{* *} \\
(0.049)\end{array}$ & $\begin{array}{l}0.139 * * \\
(0.015)\end{array}$ & $\begin{array}{l}0.305 * * \\
(0.044)\end{array}$ & $\begin{array}{l}0.143 * * \\
(0.015)\end{array}$ \\
\hline Real GDP & $\begin{array}{c}0.788^{* *} \\
(0.008)\end{array}$ & $\begin{array}{l}1.220^{* *} \\
(0.045)\end{array}$ & $\begin{array}{c}0.799 * * \\
(0.007)\end{array}$ & $\begin{array}{c}0.568 * * \\
(0.025)\end{array}$ & $\begin{array}{l}0.801 * * \\
(0.007)\end{array}$ & $\begin{array}{l}0.562 * * \\
(0.023)\end{array}$ \\
\hline Real GDP per capita & $\begin{array}{c}0.224 * * \\
(0.033)\end{array}$ & & $\begin{array}{c}0.268^{* *} \\
(0.030)\end{array}$ & & $\begin{array}{c}0.273 * * \\
(0.029)\end{array}$ & \\
\hline Distance & $\begin{array}{l}-0.763 * * \\
(0.021)\end{array}$ & & $\begin{array}{l}-0.789 * * \\
(0.021)\end{array}$ & & $\begin{array}{l}-0.789 * * \\
(0.021)\end{array}$ & \\
\hline Common Language & $\begin{array}{l}0.800 * * \\
(0.042)\end{array}$ & & $\begin{array}{l}0.718^{* *} \\
(0.037)\end{array}$ & & $\begin{array}{c}0.715^{* *} \\
(0.036)\end{array}$ & \\
\hline Common Border & $\begin{array}{c}0.243 * * \\
(0.043)\end{array}$ & & $\begin{array}{l}0.154^{* *} \\
(0.050)\end{array}$ & & $\begin{array}{l}0.159 * * \\
(0.048)\end{array}$ & \\
\hline $\begin{array}{l}\text { Free Trade } \\
\text { Agreement }\end{array}$ & $\begin{array}{c}0.092 \# \\
(0.050)\end{array}$ & $\begin{array}{l}-0.015 \\
(0.019)\end{array}$ & $\begin{array}{l}0.148^{* *} \\
(0.043)\end{array}$ & $\begin{array}{c}0.019 \\
(0.019)\end{array}$ & $\begin{array}{l}0.142 * * \\
(0.042)\end{array}$ & $\begin{array}{c}0.021 \\
(0.019)\end{array}$ \\
\hline European Union & $\begin{array}{l}0.189 * * \\
(0.044)\end{array}$ & $\begin{array}{c}0.033 \\
(0.020)\end{array}$ & $\begin{array}{l}0.214^{* *} \\
(0.042)\end{array}$ & $\begin{array}{c}0.014 \\
(0.021)\end{array}$ & $\begin{array}{l}0.220^{* *} \\
(0.040)\end{array}$ & $\begin{array}{c}0.015 \\
(0.021)\end{array}$ \\
\hline Landlocked & $\begin{array}{l}-0.481 * * \\
(0.030)\end{array}$ & & $\begin{array}{l}-0.453 * * \\
(0.031)\end{array}$ & & $\begin{array}{l}-0.448 * * \\
(0.030)\end{array}$ & \\
\hline Island & $\begin{array}{c}0.146^{* *} \\
(0.043)\end{array}$ & & $\begin{array}{l}0.215^{* *} \\
(0.031)\end{array}$ & & $\begin{array}{l}0.221 * * \\
(0.030)\end{array}$ & \\
\hline Country pair effects? & No & Yes & No & Yes & No & Yes \\
\hline Year effects? & Yes & Yes & Yes & Yes & Yes & Yes \\
\hline \# Obs. & 2,541 & 2,541 & 2,541 & 2,541 & 2,772 & 2,772 \\
\hline $\mathrm{R}^{2}$ & 0.93 & 0.45 & 0.93 & 0.42 & 0.93 & 0.44 \\
\hline
\end{tabular}

Notes:

Dependent variable is the log of bilateral trade in real US dollars.

Robust standard errors are recorded in parentheses.

$* *, *$ and \# denote significant at the 1, 5 and 10 percent levels, respectively.

Shaded columns and bolded EMU2 results mark the preferred specification with country-pair fixed effects. 
b) European countries

\begin{tabular}{|c|c|c|c|c|c|c|}
\hline Data & $\mathrm{MSO}$ & MSO & Updated & Updated & Updated & Updated \\
\hline Period & $1992-2002$ & $1992-2002$ & $1992-2002$ & $1992-2002$ & $1992-2003$ & $1992-2003$ \\
\hline EMU2 & $\begin{array}{l}0.229 * * \\
(0.041)\end{array}$ & $\begin{array}{l}0.052 * * \\
(0.014)\end{array}$ & $\begin{array}{l}0.359 * * \\
(0.042)\end{array}$ & $\begin{array}{l}0.138 * * \\
(0.015)\end{array}$ & $\begin{array}{l}0.362 * * \\
(0.038)\end{array}$ & $\begin{array}{l}0.143 * * \\
(0.015)\end{array}$ \\
\hline Real GDP & $\begin{array}{l}0.742 * * \\
(0.009)\end{array}$ & $\begin{array}{l}1.081 * * \\
(0.050)\end{array}$ & $\begin{array}{l}0.721 * * \\
(0.009)\end{array}$ & $\begin{array}{l}0.524 * * \\
(0.031)\end{array}$ & $\begin{array}{l}0.723 * * \\
(0.009)\end{array}$ & $\begin{array}{l}0.515 * * \\
(0.030)\end{array}$ \\
\hline Real GDP per capita & $\begin{array}{l}0.150^{* *} \\
(0.036)\end{array}$ & & $\begin{array}{l}0.279 * * \\
(0.032)\end{array}$ & & $\begin{array}{l}0.282 * * \\
(0.031)\end{array}$ & \\
\hline Distance & $\begin{array}{l}-0.905^{* *} \\
(0.028)\end{array}$ & & $\begin{array}{l}-1.035^{* *} \\
(0.031)\end{array}$ & & $\begin{array}{l}-1.040 * * \\
(0.030)\end{array}$ & \\
\hline Common Language & $\begin{array}{l}0.423^{* *} \\
(0.068)\end{array}$ & & $\begin{array}{l}0.392 * * \\
(0.060)\end{array}$ & & $\begin{array}{l}0.391 * * \\
(0.057)\end{array}$ & \\
\hline Common Border & $\begin{array}{l}0.297 * * \\
(0.041)\end{array}$ & & $\begin{array}{c}0.005 \\
(0.050)\end{array}$ & & $\begin{array}{c}0.003 \\
(0.048)\end{array}$ & \\
\hline $\begin{array}{l}\text { Free Trade } \\
\text { Agreement }\end{array}$ & $\begin{array}{l}-0.158^{* *} \\
(0.052)\end{array}$ & $\begin{array}{l}-0.006 \\
(0.018)\end{array}$ & $\begin{array}{l}-0.156^{* *} \\
(0.046)\end{array}$ & $\begin{array}{c}0.025 \\
(0.019)\end{array}$ & $\begin{array}{l}-0.174 * * \\
(0.045)\end{array}$ & $\begin{array}{c}0.028 \\
(0.019)\end{array}$ \\
\hline European Union & $\begin{array}{c}0.119^{*} \\
(0.047)\end{array}$ & $\begin{array}{c}0.026 \\
(0.019)\end{array}$ & $\begin{array}{l}0.131 * * \\
(0.041)\end{array}$ & $\begin{array}{c}0.021 \\
(0.021)\end{array}$ & $\begin{array}{l}0.142^{* *} \\
(0.040)\end{array}$ & $\begin{array}{c}0.022 \\
(0.020)\end{array}$ \\
\hline Landlocked & $\begin{array}{l}-0.676^{* *} \\
(0.033)\end{array}$ & & $\begin{array}{l}-0.737 * * \\
(0.032)\end{array}$ & & $\begin{array}{l}-0.734 * * \\
(0.030)\end{array}$ & \\
\hline Island & $\begin{array}{l}-0.152 * \\
(0.069) \\
\end{array}$ & & $\begin{array}{l}-0.379 * * \\
(0.052)\end{array}$ & & $\begin{array}{l}-0.352 * * \\
(0.050)\end{array}$ & \\
\hline Country pair effects? & No & Yes & No & Yes & No & Yes \\
\hline Year effects? & Yes & Yes & Yes & Yes & Yes & Yes \\
\hline \# Obs. & 1,496 & 1,496 & 1,496 & 1,496 & 1,632 & 1,632 \\
\hline $\mathrm{R}^{2}$ & 0.94 & 0.51 & 0.95 & 0.46 & 0.95 & 0.49 \\
\hline
\end{tabular}

Notes:

Dependent variable is the log of bilateral trade in real US dollars.

Robust standard errors are recorded in parentheses.

$* *, *$ and $\#$ denote significant at the 1,5 and 10 percent levels, respectively.

Shaded columns and bolded EMU2 results mark the preferred specification with country-pair fixed effects. 
Somewhat surprisingly, data revisions seem to have a large impact on the estimation results. In column four of Table 1 (using the same sample period as in MSO), the EMU coefficient is still positive and statistically highly significant, but the estimated magnitude of the coefficient is almost twice as large as suggested by MSO's original results; the point estimate of about 0.31 suggests that EMU members trade about 36 percent $(=\exp [0.31]-1)$ more with each other than with non-members or countries with separate currencies. For the country-pair fixed effects estimates (tabulated in the fifth column of Table 1), the effect seems to be even more pronounced and continues as we extend the data set to 2003 (last column). ${ }^{17}$ While it is surprisingly hard to identify country- or period-specific data revisions that explain these changes, revisions to GDP appear to be particularly influential. Restricting the sample to European countries (reported in panel b of Table 1) leaves the picture essentially unchanged.

In summary, it seems that the finding of a surge in intra-EMU trade after the adoption of a common currency becomes even more intriguing when the original MSO set-up is applied to the revised and updated data set.

\section{Zooming Out: Putting the Euro's Effect on Trade in Perspective}

After having added another year of EMU data, we now extend our data set backwards. MSO explore a sample that covers the 10-year period from 1992 to 2002; we lengthen the sample to include the entire post-war period starting in the late 1940s. Estimation results are depicted in Table 2. Turning directly to our variable of interest, the point estimates for EMU membership not only remain positive and statistically highly significant (with a t-statistic often close to 10), but also increase substantially in magnitude. The benchmark (country-pair fixed effects) estimate for the developed country sample (reported in the third column of Table 2) implies that trade between EMU members exceeds trade between countries using separate currencies by about 41 percent $(=\exp [0.34]-1)$, and even larger positive effects are found when the country-pair-specific fixed effects are dropped (second column) or the sample is restricted to European economies.

\footnotetext{
${ }^{17}$ Gomes et al. (2004) report similar findings.
} 
Table 2: The trade effect of the euro - the long run view

\begin{tabular}{|c|c|c|c|c|}
\hline Sample & Developed & Developed & Europe & Europe \\
\hline Period & $1948-2003$ & $1948-2003$ & $1948-2003$ & 1948-2003 \\
\hline EMU2 & $\begin{array}{c}0.376^{* *} \\
(0.053)\end{array}$ & $\begin{array}{l}0.343 * * \\
(0.032)\end{array}$ & $\begin{array}{l}0.462 * * \\
(0.049)\end{array}$ & $\begin{array}{l}0.437 * * \\
(0.032)\end{array}$ \\
\hline Real GDP & $\begin{array}{l}0.824 * * \\
(0.004)\end{array}$ & $\begin{array}{c}0.899 * * \\
(0.013)\end{array}$ & $\begin{array}{l}0.746^{* *} \\
(0.006)\end{array}$ & $\begin{array}{c}0.815^{* *} \\
(0.022)\end{array}$ \\
\hline Real GDP per capita & $\begin{array}{l}0.187 * * \\
(0.010)\end{array}$ & & $\begin{array}{l}0.316^{* *} \\
(0.013)\end{array}$ & \\
\hline Distance & $\begin{array}{l}-0.817^{* *} \\
(0.010)\end{array}$ & & $\begin{array}{l}-0.921 * * \\
(0.019)\end{array}$ & \\
\hline Common Language & $\begin{array}{l}0.763 * * \\
(0.021)\end{array}$ & & $\begin{array}{l}0.724 * * \\
(0.037)\end{array}$ & \\
\hline Common Border & $\begin{array}{c}0.009 \\
(0.028)\end{array}$ & & $\begin{array}{l}-0.099 * * \\
(0.031)\end{array}$ & \\
\hline $\begin{array}{l}\text { Free Trade } \\
\text { Agreement }\end{array}$ & $\begin{array}{l}0.543 * * \\
(0.024)\end{array}$ & $\begin{array}{c}0.194^{* *} \\
(0.017)\end{array}$ & $\begin{array}{l}0.462 * * \\
(0.022)\end{array}$ & $\begin{array}{c}0.182 * * \\
(0.017) \\
\end{array}$ \\
\hline European Union & $\begin{array}{l}-0.167^{* *} \\
(0.029)\end{array}$ & $\begin{array}{l}0.203 * * \\
(0.022)\end{array}$ & $\begin{array}{l}-0.198 * * \\
(0.028)\end{array}$ & $\begin{array}{c}0.240^{* *} \\
(0.021)\end{array}$ \\
\hline Landlocked & $\begin{array}{l}-0.399 * * \\
(0.017)\end{array}$ & & $\begin{array}{l}-0.600 * * \\
(0.018)\end{array}$ & \\
\hline Island & $\begin{array}{c}0.313 * * \\
(0.017)\end{array}$ & & $\begin{array}{l}-0.327 * * \\
(0.032)\end{array}$ & \\
\hline Country pair effects? & No & Yes & No & Yes \\
\hline Year effects? & Yes & Yes & Yes & Yes \\
\hline \# Obs. & 12,150 & 12,157 & 7,124 & 7,128 \\
\hline $\mathrm{R}^{2}$ & 0.91 & 0.85 & 0.93 & 0.88 \\
\hline
\end{tabular}

Notes:

Dependent variable is the log of bilateral trade in real US dollars.

Robust standard errors are recorded in parentheses.

$* *, *$ and \# denote significant at the 1, 5 and 10 percent levels, respectively.

Shaded columns and bolded EMU2 results mark the preferred specification with country-pair fixed effects. 
A possible explanation for this dramatic increase in the estimated EMU effect is that the additional inclusion of trade observations before 1992 lowers the sample average of bilateral trade flows, thereby further highlighting the above-average tendency to trade between EMU member countries. In view of this obvious dependence of the estimated EMU effect on the sample period, it appears to be even more important to put the trade-creating effects of EMU in historical perspective. ${ }^{18}$ We now turn to that task.

There are essentially two approaches to analyze the evolution of trade (or, more precisely, the development of cross-country variation in bilateral trade) over time. A first approach is to run separate regressions for every single year in the sample. The coefficient on the currency union dummy then captures, year by year, the extent to which trade between (future) EMU member countries deviates from the sample average, after controlling for other factors. Alternatively, one can estimate a pooled regression for the full sample period, adding separate annual currency union dummies. In contrast to the previous approach, this specification requires the coefficients on the control variables to be constant over time. In practice, however, it turns out that the results for both models are largely identical. Figure 1 plots the coefficient estimates on the EMU dummy for both specifications; panel a shows the results for the full country sample and panel $b$ the coefficient estimates for the subgroup of European countries. Accompanying estimation results for 10-year periods are reported in Table 3.

The most notable observation from Figure 1 (and also Table 3 ) is a strong positive long-term trend in the bilateral tendency to trade between the countries that later join EMU. Trade between future EMU members was still significantly below the sample average in the wake of World War II. Since then, however, trade has increased over a span of more than five decades to levels clearly, and significantly, above average trade within the sample. Against this backdrop, the increase in intra-EMU trade that we (and others) observe after the formation of EMU is largely a continuation of a remarkable longer-term trend. Arguably, Figure 1 still hints at a euro effect, but the increase in trade is small when compared with the long-term trend driving intra-EMU trade long before the inception of a common currency at the end of the 1990s.

\footnotetext{
${ }^{18}$ Bun and Klaassen (2004) also note a positive association between the sample period and the estimated impact of the euro on trade.
} 
Figure 1: Evolution of trade intensity between EMU11 countries over time

a) Developed countries

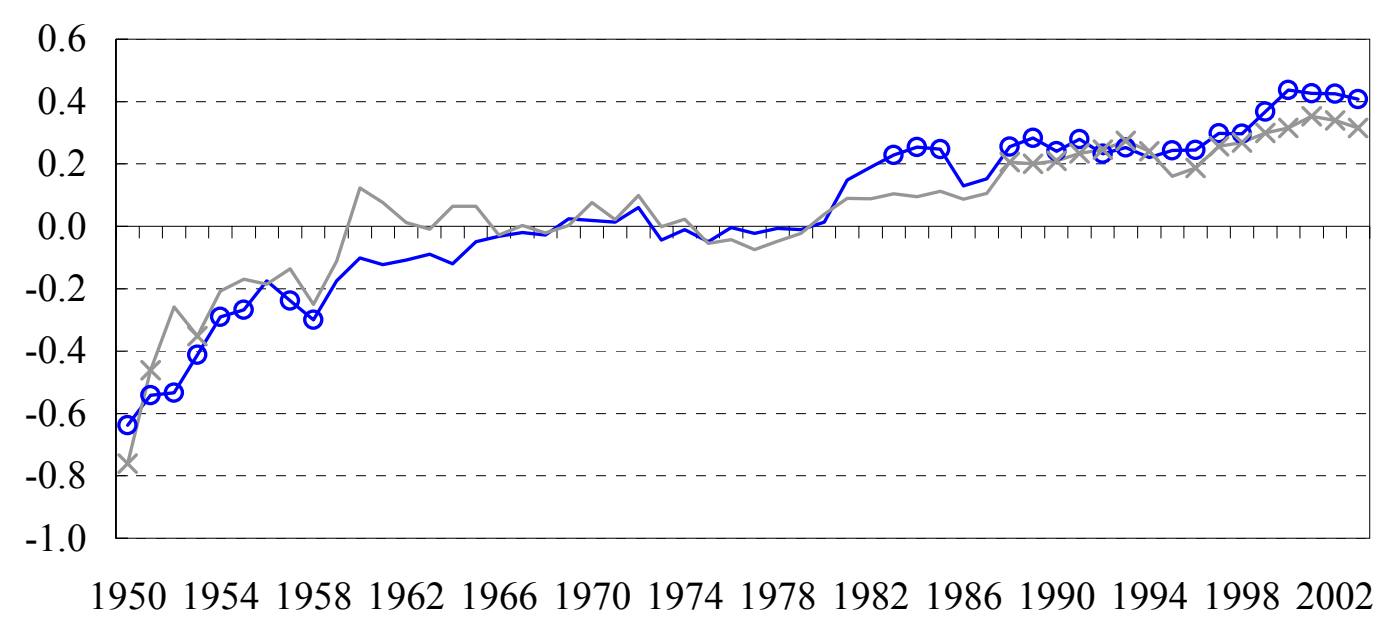

Notes: Line with circles (crosses) reports estimated coefficients derived from pooled (yearly) regressions. A circle/cross indicates that the coefficient is significant at the $5 \%$ level.

b) European countries

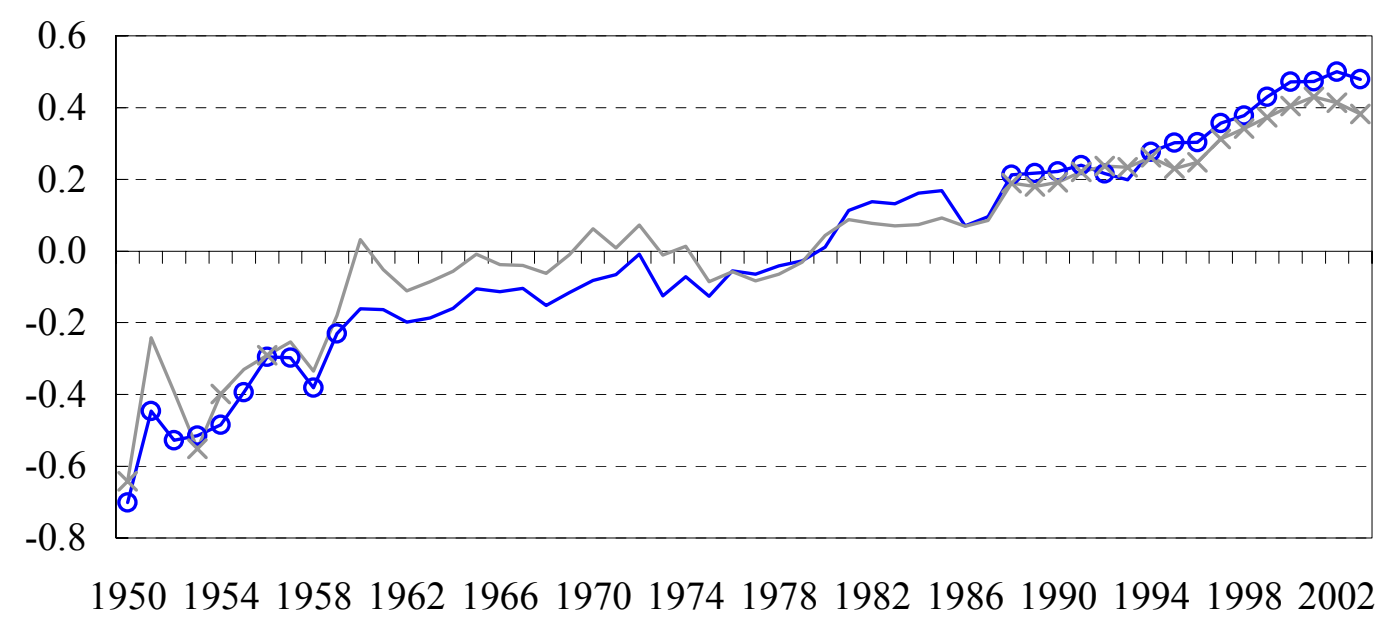

Notes: Line with circles (crosses) reports estimated coefficients derived from pooled (yearly) regressions. A circle/cross indicates that the coefficient is significant at the 5\% level. 
Table 3: Trade intensities between EMU members over time

\begin{tabular}{|l|l|l|l|}
\hline Sample & Developed & & \\
\hline & EMU11 & \# Obs. & R2 \\
\hline Period & & & \\
\hline $1950-59$ & $\begin{array}{l}\mathbf{- 0 . 2 2 0 * *} \\
(\mathbf{0 . 0 5 7})\end{array}$ & 1,933 & 0.80 \\
\hline $1960-69$ & $\begin{array}{l}\mathbf{0 . 0 3 0} \\
\mathbf{( 0 . 0 4 5 )}\end{array}$ & 2,298 & 0.88 \\
\hline $1970-79$ & $\begin{array}{l}\mathbf{0 . 0 0 0} \\
(\mathbf{0 . 0 3 0})\end{array}$ & 2,310 & 0.91 \\
\hline $1980-89$ & $\begin{array}{l}\mathbf{0 . 1 0 3} * * \\
(\mathbf{0 . 0 2 5})\end{array}$ & 2,310 & 0.93 \\
\hline $1990-98$ & $\begin{array}{l}\mathbf{0 . 2 4 8} * \\
(\mathbf{0 . 0 2 4})\end{array}$ & 2,079 & 0.93 \\
\hline $1999-2003$ & $\begin{array}{l}\mathbf{0 . 3 2 4} * * \\
(\mathbf{0 . 0 3 8})\end{array}$ & 1,155 & 0.93 \\
\hline & & & \\
\hline $\begin{array}{l}\text { Country pair } \\
\text { effects? }\end{array}$ & No & & \\
\hline Year effects? & Yes & & \\
\hline
\end{tabular}

\begin{tabular}{|l|l|l|l|}
\hline Sample & European & & \\
\hline & EMU11 & \# Obs. & R2 \\
\hline Period & & & \\
\hline $1950-59$ & $\begin{array}{l}\mathbf{- 0 . 3 4 8 * *} \\
(\mathbf{0 . 0 6 0 )}\end{array}$ & 1,120 & 0.85 \\
\hline $1960-69$ & $\begin{array}{l}\mathbf{- 0 . 0 4 5} \\
\mathbf{( 0 . 0 4 6 )}\end{array}$ & 1,360 & 0.91 \\
\hline $1970-79$ & $\begin{array}{l}\mathbf{- 0 . 0 1 2} \\
(\mathbf{0 . 0 2 9})\end{array}$ & 1,360 & 0.93 \\
\hline $1980-89$ & $\begin{array}{l}\mathbf{0 . 0 8 9} * * \\
(\mathbf{0 . 0 2 4})\end{array}$ & 1,360 & 0.94 \\
\hline $1990-98$ & $\begin{array}{l}\mathbf{0 . 2 4 3} * * \\
(\mathbf{0 . 0 2 3 )}\end{array}$ & 1,224 & 0.95 \\
\hline $1999-2003$ & $\begin{array}{l}\mathbf{0 . 4 0 0 * *} \\
(\mathbf{0 . 0 3 6 )}\end{array}$ & 680 & 0.95 \\
\hline & & & \\
\hline $\begin{array}{l}\text { Country pair } \\
\text { effects? }\end{array}$ & No & & \\
\hline Year effects? & Yes & & \\
\hline
\end{tabular}

Notes:

Dependent variable is the log of bilateral trade in real US dollars.

Robust standard errors are recorded in parentheses.

$* *$, ${ }^{*}$ and \# denote significant at the 1, 5 and 10 percent levels, respectively.

The following variables are included in the regressions, but coefficients are not reported: real GDP, real GDP per capita, distance, common language, common border, free trade agreement, European Union dummy, landlocked, and island.

Shaded columns mark the preferred specification with country-pair fixed effects. 
Figure 2: Evolution of trade intensity between EMU11 countries over time (with country-pair fixed effects)

a) Developed countries

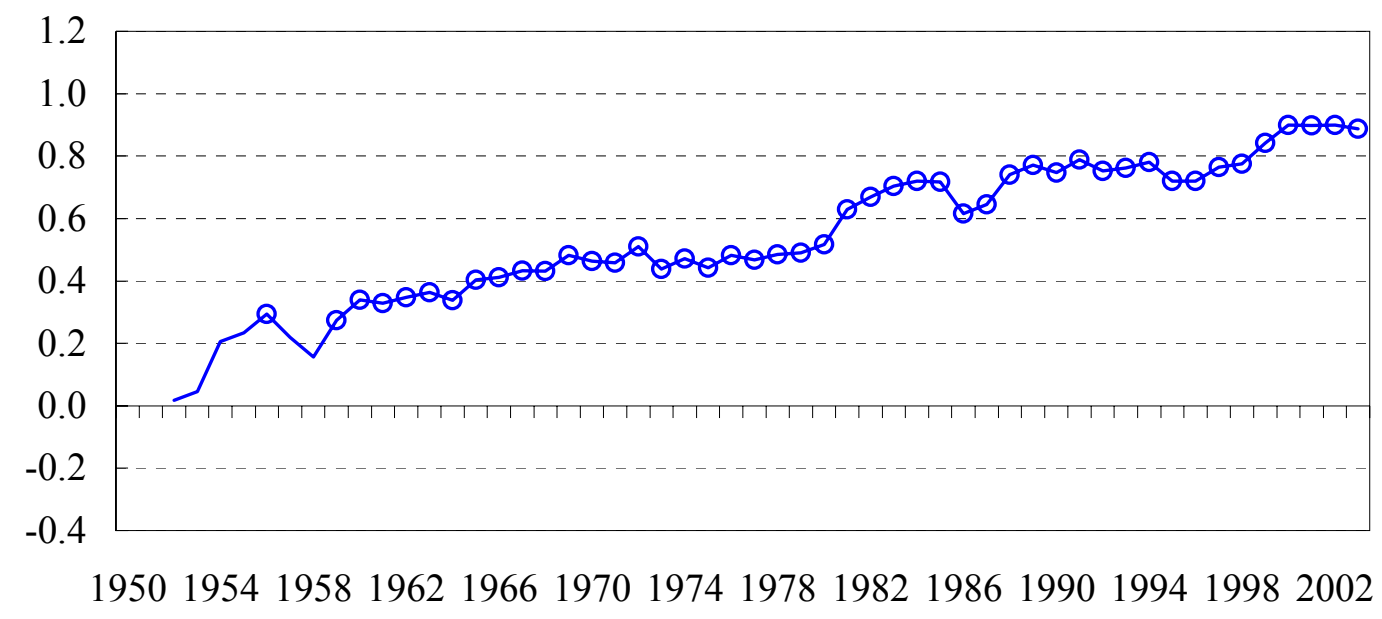

Notes: Line reports estimated coefficients derived from pooled regressions. A circle indicates that the coefficient is significant at the $5 \%$ level.

b) European countries

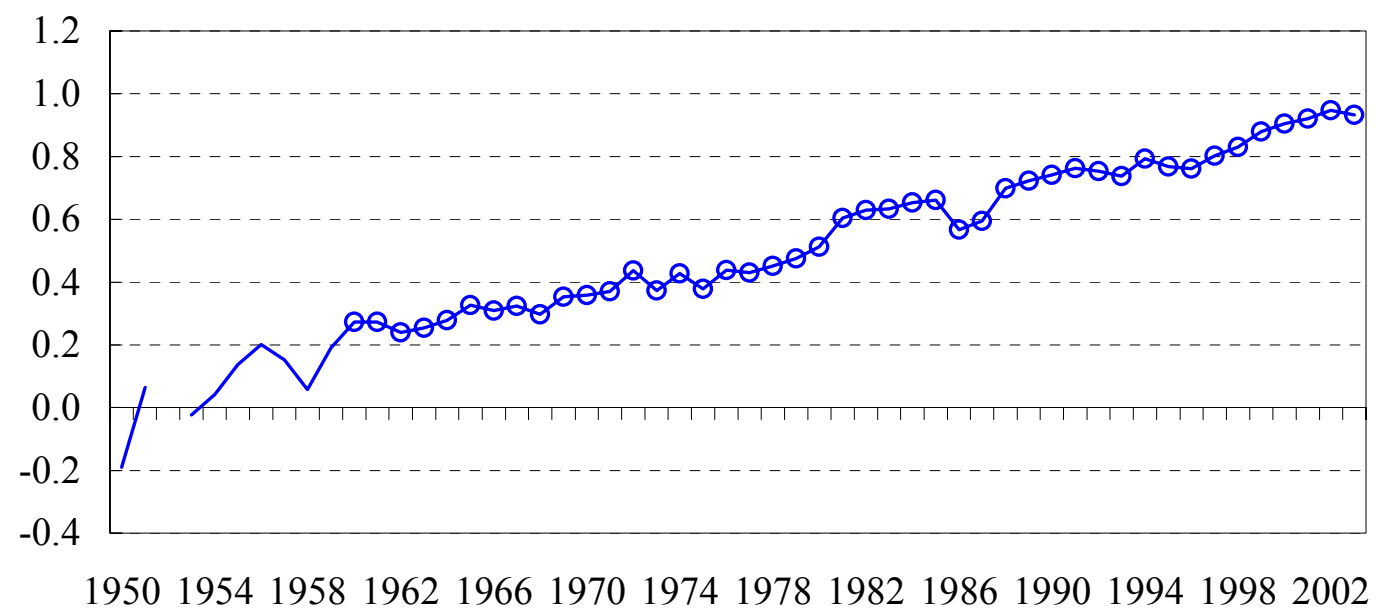

Notes: Line reports estimated coefficients derived from pooled regressions. A circle indicates that the coefficient is significant at the $5 \%$ level. 
Whether the positive trend in intra-EMU trade vis-à-vis the rest of the sample is continuous over time partly depends on the country sample that is used as control group. Relative to trade between all developed countries in the sample, intra-EMU trade grew in spurts, with the 1950s and 1980s being exceptionally dynamic periods, while the late 1960s and the 1970 s were periods of relative stagnation. This general pattern is still discernable when the control group is restricted to European countries. However, relative EMU trade growth appears to have been somewhat more stable in this sample.

The long-term upward trend in intra-EMU trade also remains intact after the introduction of country-pair fixed effects to control for any unobserved time-invariant determinants. Figure 2 illustrates that, with this modification, there is still clear evidence of a gradual increase in bilateral trade among future EMU economies. Note that the estimated values for the time-variant EMU dummies are consistently positive in this specification, since the country-pair fixed effects control for the average deviation of intra-EMU trade from the mean of the sample.

\section{Explaining the Evolution of Intra-EMU Trade}

What could explain this particular time pattern in the evolution of intra-EMU trade? The growth spurt in the immediate post-war period seems to reflect the rapid re-emergence of pre-war patterns in European trade, fostered by institutions that were established under the auspices of the Marshall plan, including the European Payments Union. These institutions helped to overcome problems of convertibility and alleviated the notorious European trade deficit with the US by re-integrating the German economy into the European network of trading partners; see, for instance, Berger and Ritschl (1995).

The reestablishment of trade patterns was accompanied by the formal harmonization of tariffs, regulation, and economic policies, efforts that finally led to the founding of the European Economic Community (EEC) in 1957 and of the European Free Trade Agreement (EFTA) in 1960; Appendix 2 provides a broad timeline of important steps towards European integration. While institutional integration slowed somewhat during the 1960s, it was rejuvenated in the late 1970s when - in the aftermath of the demise of the Bretton Woods 
system-European monetary cooperation took shape. ${ }^{19}$ After another period of low activity in the early 1980s (often denoted as 'euro-pessimism'), the integration process re-intensified again in the second half of the 1980s with the preparation and passing of the Single European Act (which set up the single market framework), a streamlining of the work of the European Commission, and the start of the political process that culminated in the Maastricht Treaty of 1991.

While there is no obvious link between the landmarks of institutional integration and the particular time pattern in the evolution of intra-EMU trade that we observe empirically, it seems likely that the two are related. In particular, it would seem that - from the institutional perspective - the establishment of the EMU in 1999 was just another step in the longdeveloping movement toward increased integration and greater convergence. As a result, trade relations between EMU members intensified after 1999 as they intensified over the previous several decades in response to earlier efforts to increase integration.

Continuing along this line but trying to go beyond the narrative, we further explore this issue by expanding our econometric model. Thereby, we aim to shed some light on the factors underlying the time path of intra-EMU trade

\section{Exchange Rate Stability}

We begin by examining a measure of exchange rate volatility. In the actual implementation, we use the standard deviation of the mean monthly bilateral exchange rate in the year of interest. ${ }^{20}$ The data were obtained from the IMF's International Financial Statistics and are available (only) from 1957 onwards. Figure 3 portrays the evolution of exchange rate volatility over the sample period; the graph shows that our volatility measure basically follows an inverted U-shaped pattern.

Interestingly, periods for which we observe a rapid increase in trade integration in Europe, at the beginning and at the end of our sample period (the 1950s and 1960s under the Bretton Woods system and the late 1980s and early 1990s under the European Monetary System [EMS], respectively), are typically associated with low exchange rate volatility.

\footnotetext{
${ }^{19}$ The European Monetary System entered into force in March 1979. In the same year the European Parliament was, for the first time, elected directly by European voters.

${ }^{20}$ Note that the construction of the exchange rate variable allows for bilateral differences in exchange rate volatility. Modifications of this measure, such as using lagged or average values, have no effect on our findings. Alternative results available on request.
} 
Figure 3: Exchange rate volatility

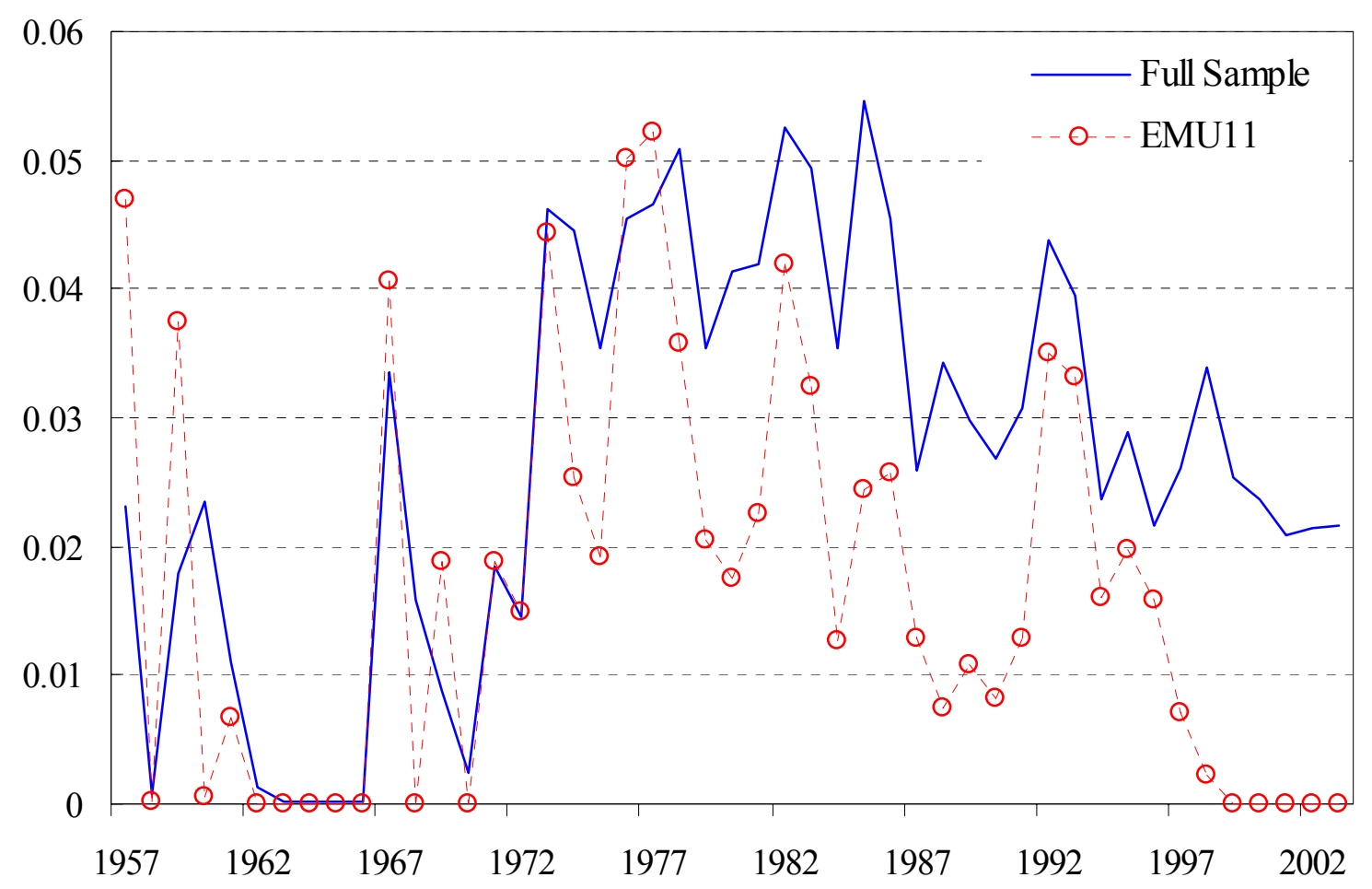

Notes: The graph shows the average yearly standard deviation in bilateral exchange rates. 
Table 4: Controlling for exchange rate volatility

\begin{tabular}{|l|l|l|l|l|}
\hline Sample & Developed & Developed & Developed & Developed \\
\hline Period & $1957-2003$ & $1957-2003$ & $1957-2003$ & $1957-2003$ \\
\hline & & & & \\
\hline EMU2 & $0.375^{* *}$ & $\mathbf{0 . 3 2 9 * *}$ & $\begin{array}{l}0.338^{* *} \\
(0.050)\end{array}$ & $\begin{array}{l}\mathbf{0 . 3 1 9 * *} \\
(\mathbf{0 . 0 3 6})\end{array}$ \\
\hline $\begin{array}{l}\text { Exchange rate } \\
\text { volatility }\end{array}$ & & & $\begin{array}{l}-2.580^{* *} \\
(0.050)\end{array}$ & $\begin{array}{l}-0.705^{* *} \\
(0.138)\end{array}$ \\
\hline & & & & \\
\hline Country pair effects? & No & Yes & No & Yes \\
\hline Year effects? & Yes & Yes & Yes & Yes \\
\hline & & & & \\
\hline$\#$ Obs. & 10,835 & 10,835 & 10,835 & 10,835 \\
\hline $\mathrm{R}^{2}$ & 0.91 & 0.85 & 0.91 & 0.85 \\
\hline
\end{tabular}

\begin{tabular}{|l|l|l|l|l|}
\hline Sample & Europe & Europe & Europe & Europe \\
\hline Period & $1957-2003$ & $1957-2003$ & $1957-2003$ & $1957-2003$ \\
\hline & & & & \\
\hline EMU2 & $\begin{array}{l}0.461^{* *} \\
(0.046)\end{array}$ & $\begin{array}{l}\mathbf{0 . 4 0 6 * *} \\
\mathbf{( 0 . 0 2 9 )}\end{array}$ & $\begin{array}{l}0.460^{* *} \\
(0.046\end{array}$ & $\begin{array}{l}\mathbf{0 . 4 0 0 * *} \\
(\mathbf{0 . 0 3 5})\end{array}$ \\
\hline $\begin{array}{l}\text { Exchange rate } \\
\text { volatility }\end{array}$ & & & $\begin{array}{l}-0.054 \\
(0.273)\end{array}$ & $\begin{array}{l}-0.608^{* *} \\
(0.168)\end{array}$ \\
\hline & & & & \\
\hline Country pair effects? & No & Yes & No & Yes \\
\hline Year effects? & Yes & Yes & Yes & Yes \\
\hline & & & & \\
\hline$\#$ Obs. & 6,389 & 6,389 & 6,389 & 6,389 \\
\hline $\mathrm{R}^{2}$ & 0.93 & 0.88 & 0.93 & 0.88 \\
\hline
\end{tabular}

Notes:

Dependent variable is the log of bilateral trade in real US dollars.

Robust standard errors are recorded in parentheses.

$* *, *$ and $\#$ denote significant at the 1, 5 and 10 percent levels, respectively.

The following variables are included in the regressions, but coefficients are not reported: real GDP, real GDP per capita, distance, common language, common border, free trade agreement, European Union dummy, landlocked, and island.

Shaded columns and bolded EMU2 results mark the preferred specification with country-pair fixed effects. 
Table 4 reports the regression results. The coefficient on exchange rate volatility takes on the expected (negative) sign and is significant in most specifications; that is, stable exchange rates tend to promote trade. However, with the additional inclusion of this variable, the estimates for the EMU dummy fall only marginally. In the preferred model with countrypair fixed effects, the estimated EMU effect drops by about 3 percent (1 percent in the European sample). While this points in the expected direction, including exchange rate volatility largely fails to capture the long-term trend in EMU trade intensity.

\section{$\underline{\text { Institutional Integration }}$}

In a second extension of the basic model, we add a (country-specific) measure of institutional integration in Europe. Since no comprehensive indicator is readily available, we define an (albeit crude) index of integration. The index combines information from three different sources, each summarizing important elements of the integration process in Europe over a certain period. For each of these three measures, the index is defined to vary between 0 (no liberalization) and 10 (full liberalization) index points, so that the overall index ranges from 0 to $30(=3 * 10)$. Figure 4 graphs the sample average of the index, along with minimum and maximum values. In the regression analysis, we take the pair-wise minimum of the country-specific degree of integration; alternative specifications, including the pair-wise mean, yield basically similar results.

The index is constructed as follows. For the 1950s, we obtain information on the percentage of intra-European trade that is freed from quantitative restrictions. The data are available from the Organization for European Economic Co-operation (OEEC) on a bi-annual basis for the period from 1950 through 1961 for 17 major European countries; we take midyear figures from the OEEC's final (1961) Annual Economic Review (Table 35) and divide these percentages by 10 . At the beginning of the period, about one-half of private imports among the member countries were free of quotas. In the following years, this figure rapidly increased and often reached values significantly above 90 percent by 1956 .

Beginning in the late 1950s, trade liberalization was increasingly carried out within subgroups of countries - most prominently in the EEC and the EFTA; see Appendix 2. The gradual phase-out of tariffs within, and between, these groupings is captured by an average tariff index that we take from Table 2 in Ben-David (1993). This tariff index is set to 100 in 
Figure 4: Index of European integration

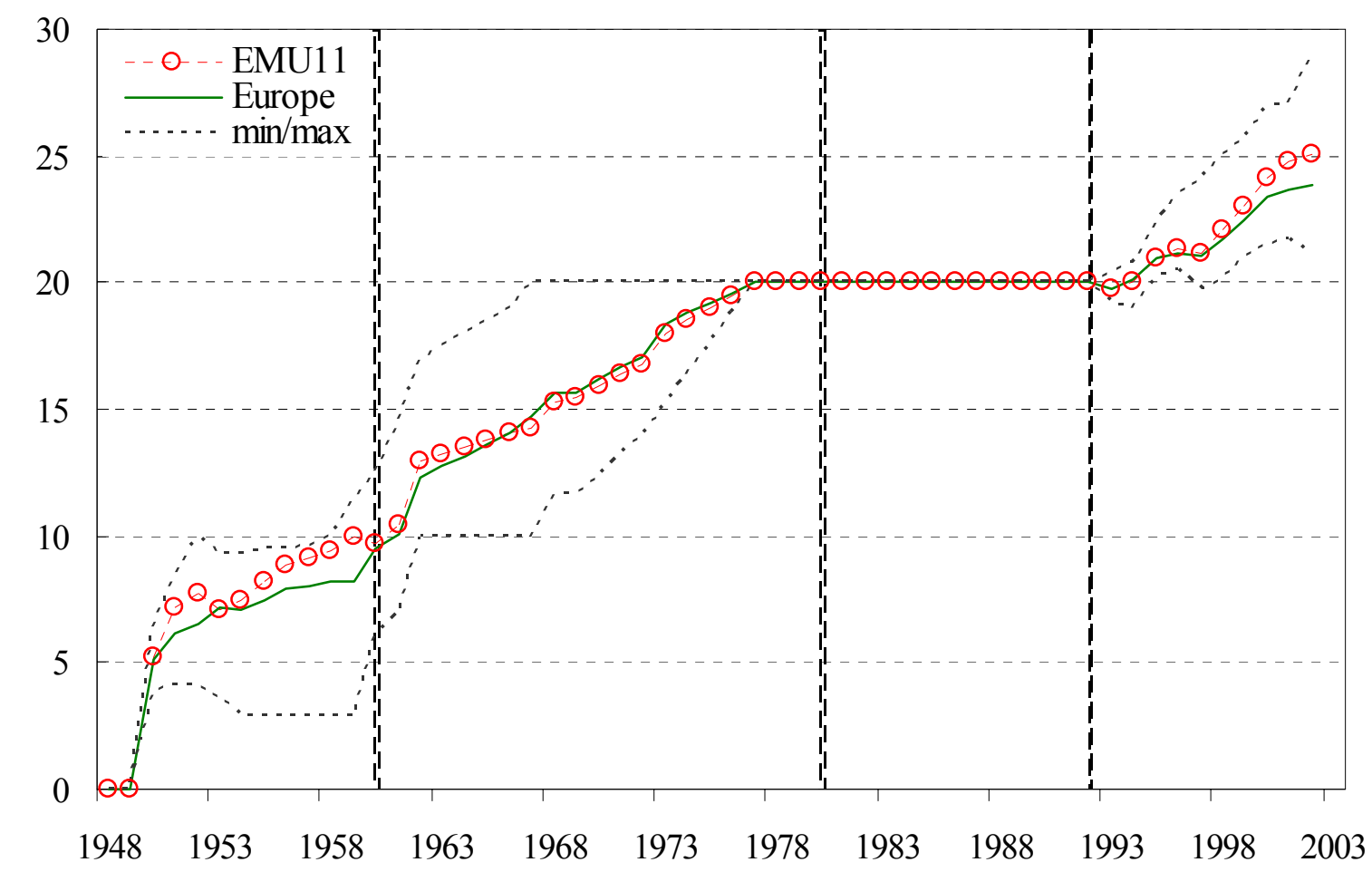


Table 5: Controlling for European integration

\begin{tabular}{|l|l|l|l|l|}
\hline Sample & Developed & Developed & Developed & Developed \\
\hline Period & $1950-2002$ & $1950-2002$ & $1950-2002$ & $1950-2002$ \\
\hline & & & & \\
\hline EMU2 & $\begin{array}{c}0.392^{* *} \\
(0.059)\end{array}$ & $\begin{array}{c}\mathbf{0 . 2 9 5} \\
\mathbf{( 0 . 0 3 3 )}\end{array}$ & $\begin{array}{c}0.280^{* *} \\
(0.059)\end{array}$ & $\begin{array}{c}\mathbf{0 . 2 7 5 * *} \\
(\mathbf{0 . 0 3 4})\end{array}$ \\
\hline $\begin{array}{l}\text { Index of European } \\
\text { integration }\end{array}$ & & & $\begin{array}{c}0.025^{* *} \\
(0.002)\end{array}$ & $\begin{array}{c}0.007^{* *} \\
(0.002)\end{array}$ \\
\hline & & & & \\
\hline Country pair effects? & No & Yes & No & Yes \\
\hline Year effects? & Yes & Yes & Yes & Yes \\
\hline & & & & \\
\hline$\#$ Obs. & 10,365 & 10,365 & 10,365 & 10,323 \\
\hline $\mathrm{R}^{2}$ & 0.90 & 0.86 & 0.91 & 0.86 \\
\hline
\end{tabular}

\begin{tabular}{|l|l|l|l|l|}
\hline Sample & Europe & Europe & Europe & Europe \\
\hline Period & $1950-2002$ & $1950-2002$ & $1950-2002$ & $1950-2002$ \\
\hline & & & & \\
\hline EMU2 & $\begin{array}{c}0.501^{* *} \\
(0.053)\end{array}$ & $\begin{array}{l}\mathbf{0 . 3 9 0 * *} \\
\mathbf{( 0 . 0 3 0 )}\end{array}$ & $\begin{array}{c}0.443^{* *} \\
(0.053)\end{array}$ & $\begin{array}{c}\mathbf{0 . 3 6 9} * * \\
(\mathbf{0 . 0 3 1})\end{array}$ \\
\hline $\begin{array}{l}\text { Index of European } \\
\text { integration }\end{array}$ & & & $\begin{array}{c}0.034^{* *} \\
(0.005)\end{array}$ & $\begin{array}{c}0.011^{* *} \\
(0.003)\end{array}$ \\
\hline & & & & \\
\hline Country pair effects? & No & Yes & No & Yes \\
\hline Year effects? & Yes & Yes & Yes & Yes \\
\hline & & & & \\
\hline$\#$ Obs. & 5,479 & 5,479 & 5,479 & 5,479 \\
\hline $\mathrm{R}^{2}$ & 0.93 & 0.91 & 0.93 & 0.91 \\
\hline
\end{tabular}

Notes:

Dependent variable is the log of bilateral trade in real US dollars.

Robust standard errors are recorded in parentheses.

**,* and \# denote significant at the 1, 5 and 10 percent levels, respectively.

The following variables are included in the regressions, but coefficients are not reported: real GDP, real GDP per capita, distance, common language, common border, free trade agreement, European Union dummy, landlocked, and island.

Shaded columns and bolded EMU2 results mark the preferred specification with country-pair fixed effects. 
1958 and gradually falls to 0 in 1967 (for intra-EFTA trade), 1968 (for intra-EEC trade) and 1977 (for EEC-EFTA trade). In the actual implementation of this tariff measure, we obtain our overall index of European trade integration during this period by adding the difference between 100 and the actual tariff index, divided by 10 , to the starting value of 10 .

The late 1970 s and early 1980 s were characterized by less dynamic real economic integration and liberalization efforts than previous periods, with the exception of some political progress and the rise of the EMS (which helped providing stable exchange rates). Thus, with other variables available to capture exchange rate stability (see above), our measure of European economic integration remains unchanged during this period.

Finally, attempts to eliminate the remaining barriers to the free movement of goods, services, capital and workers within Europe re-intensified in the mid-1980s, culminating in the introduction of the single market framework in 1992. At this time, the European Commission began to track the integration policies of individual member states with the help of an Internal Market Index (among other measures). This index is a composite measure of 12 indicators, including various prices (e.g. for electricity and gas) and intra-EU trade and investment. ${ }^{21}$ We use this index and normalize it so that it takes the value of 20 in the base year 1992 and that a doubling in the index equals 10 index points.

Table 5 shows the results when our measure of institutional integration is added to the gravity model. The estimated coefficient on the integration index is positive and statistically significant in all specifications, indicating that trade between more liberalized European countries is indeed disproportionately large. Moreover, the economic impact of the integration measure is sizable. As shown in Figure 4, the index increases on average from 0 to about 25 over the sample period. Thus, the point estimate in the preferred fixed effects model implies an impact of European integration on trade of about 19 percent $(=\exp [0.007 * 25]-1)$ in the allcountries sample.

To calculate the full impact of EU integration on trade, however, also the timeinvariant effect of EU membership (captured by the EU and FTA dummies) has to be taken into account. Their combined trade-enhancing effect is about 33 percent in the full sample

\footnotetext{
${ }^{21}$ See http://europa.eu.int/comm/internal_market/score/index_en.htm for a more detailed description.
} 
(coefficient estimates are not reported), implying an overall integration effect of about 58 percent; the comparable figure for the smaller European sample is 81 percent. $^{22}$

The overall long-term effect of European integration by far exceeds the estimated trade effect of the euro. The inclusion of the integration measure reduces the estimated trade effect of the euro, but the impact is modest. The point estimate for the EMU dummy falls by about one-third for the pooled OLS estimation and by just one-tenth for the preferred fixed effects specification. The point estimate of 0.27 implies that trade between EMU members is estimated to be about 31 percent higher in the full sample for the preferred model. ${ }^{23}$ This also suggests, however, that the estimated impact of EMU membership on trade remains considerably smaller than the overall effect of European trade integration (see above). Based on our crude integration measures, the integration effect seems to be almost twice as large as the common currency effect on trade.

\section{Controlling for Trend Integration}

Finally, to more fully describe the development of intra-EMU trade across time we add a time trend to our preferred specification. ${ }^{24}$ While somewhat less refined than the indexbased set-up discussed above, introducing a time trend adds considerable flexibility to the econometric model that should help identifying the underlying dynamics of intra-EMU trade.

Table 6 shows that the introduction of a simple linear trend completely eliminates the effect of the introduction of the euro on trade intensity (panel a). In the preferred specification with country-pair fixed effects, the point estimate on EMU membership is statistically indifferent from zero (for the full country sample) and even becomes marginally negative. Also in the smaller European sample, the coefficient is no longer significantly positive. At the same time, the trend coefficient is positive and statistically highly significant across samples. In other words, there is no trade effect from the introduction of the euro in addition to the post-war trend of increasing trade integration.

\footnotetext{
${ }^{22}$ The figures for the European sample are about 33 percent for the integration effect and about 36 percent for the combined EU and FTA dummies.

${ }^{23}$ These results for the integration measure seem to be robust across alternative model specifications. For instance, interacting the integration index with the EMU2 dummy hardly changes the point estimate on the index itself, while the significance level of the euro effect is reduced to the 15 percent level. Results are not reported, but available on request.

${ }^{24}$ Bun and Klaassen (2004) propose a similar approach; they apply country-pair specific time trends for shorter sample periods.
} 
Table 6: Controlling for the long-term trend in EMU trade intensities

a) Linear trend

\begin{tabular}{|l|l|l|l|l|}
\hline Sample & Developed & Developed & Europe & Europe \\
\hline Period & $1948-2003$ & $1948-2003$ & $1948-2003$ & $1948-2003$ \\
\hline & & & & \\
\hline EMU2 & $0.209^{* *}$ & $\mathbf{- 0 . 0 0 1}$ & $\begin{array}{l}0.327^{* *} \\
(0.055)\end{array}$ & $\begin{array}{l}\mathbf{0 . 0 1 9} \\
(\mathbf{0 . 0 3 5})\end{array}$ \\
\hline $\begin{array}{l}\text { Common time trend } \\
\text { for EMU11 countries }\end{array}$ & $\begin{array}{c}0.004^{* *} \\
(0.001)\end{array}$ & $\begin{array}{c}0.015^{* *} \\
(0.001)\end{array}$ & $\begin{array}{c}0.003^{* *} \\
(0.001)\end{array}$ & $\begin{array}{c}0.017^{* *} \\
(0.001)\end{array}$ \\
\hline & & & & \\
\hline Country pair effects? & No & Yes & No & Yes \\
\hline Year effects? & Yes & Yes & Yes & Yes \\
\hline & & & & \\
\hline \# Obs. & 12,150 & 12,157 & 7,124 & 7,128 \\
\hline $\mathrm{R}^{2}$ & 0.91 & 0.86 & 0.93 & 0.89 \\
\hline
\end{tabular}

Notes:

Dependent variable is the log of bilateral trade in real US dollars.

Robust standard errors are recorded in parentheses.

$* *, *$ and $\#$ denote significant at the 1,5 and 10 percent levels, respectively.

The following variables are included in the regressions, but coefficients are not reported: real GDP, real GDP per capita, distance, common language, common border, free trade agreement, European Union dummy, landlocked, and island.

Shaded columns and bolded EMU2 results mark the preferred specification with country-pair fixed effects. 
b) Quadratic trend

\begin{tabular}{|c|c|c|c|c|}
\hline Sample & Developed & Developed & Europe & Europe \\
\hline Period & $1948-2003$ & $1948-2003$ & $1948-2003$ & $1948-2003$ \\
\hline EMU2 & $\begin{array}{l}-\mathbf{- 0 . 0 7 0} \\
(0.073)\end{array}$ & $\begin{array}{c}0.087 \# \\
(0.045)\end{array}$ & $\begin{array}{l}-\mathbf{- 0 . 1 0 4} \\
(0.068)\end{array}$ & $\begin{array}{l}0.053 \\
(0.044)\end{array}$ \\
\hline $\begin{array}{l}\text { Common time trend } \\
\text { for EMU11 countries }\end{array}$ & $\begin{array}{l}-0.010^{* *} \\
(0.002)\end{array}$ & $\begin{array}{l}0.025^{* *} \\
(0.003)\end{array}$ & $\begin{array}{l}-0.018^{* *} \\
(0.002)\end{array}$ & $\begin{array}{l}0.021^{* *} \\
(0.003)\end{array}$ \\
\hline $\begin{array}{l}\text { (Common time trend } \\
\text { for EMU11 countries) }\end{array}$ & $\begin{array}{l}0.035^{* *} \\
(0.006) \\
\end{array}$ & $\begin{array}{l}-0.018^{* *} \\
(0.006)\end{array}$ & $\begin{array}{l}0.054 * * \\
(0.005)\end{array}$ & $\begin{array}{l}-0.007 \\
(0.006) \\
\end{array}$ \\
\hline Country pair effects? & $\mathrm{No}$ & Yes & No & Yes \\
\hline Year effects? & Yes & Yes & Yes & Yes \\
\hline \# Obs. & 12,150 & 12,157 & 7,124 & 7,128 \\
\hline $\mathrm{R}^{2}$ & 0.91 & 0.86 & 0.93 & 0.89 \\
\hline
\end{tabular}

Notes:

Dependent variable is the log of bilateral trade in real US dollars.

Robust standard errors are recorded in parentheses.

**,* and \# denote significant at the 1, 5 and 10 percent levels, respectively.

The following variables are included in the regressions, but coefficients are not reported: real GDP, real GDP per capita, distance, common language, common border, free trade agreement, European Union dummy, landlocked, and island.

Coefficients and standard errors for the quadratic time trend are multiplied by 100. A Wald test shows that the coefficients on the linear trend and the quadratic trend are jointly significant.

Shaded columns and bolded EMU2 results mark the preferred specification with country-pair fixed effects. 
Table 7: First differences

a) Developed countries

\begin{tabular}{|l|l|l|l|l|l|l|}
\hline Sample & Developed & Developed & Developed & Developed & Developed & Developed \\
\hline Period & $1948-2003$ & $1948-2003$ & $1948-2003$ & $1948-2003$ & $1948-2003$ & $1948-2003$ \\
\hline & & & & & & \\
\hline$\Delta$ EMU2 & 0.052 & & & $\mathbf{0 . 0 3 4}$ & & \\
& $(0.032)$ & & & $(\mathbf{0 . 0 3 3})$ & & \\
\hline EMU2 & & 0.020 & 0.010 & & $\mathbf{0 . 0 0 3}$ & $\mathbf{- 0 . 0 0 3}$ \\
& & $(0.014)$ & $(0.015)$ & & $(\mathbf{0 . 0 1 5})$ & $(\mathbf{0 . 0 1 6})$ \\
\hline$\Delta$ Real GDP & -0.075 & -0.069 & 0.001 & 0.035 & 0.038 & -0.014 \\
& $(0.184)$ & $(0.184)$ & $(0.188)$ & $(0.228)$ & $(0.228)$ & $(0.228)$ \\
\hline$\Delta$ Real GDP per capita & $0.554^{* *}$ & $0.547^{* *}$ & $0.476^{*}$ & $0.430 \#$ & $0.426 \#$ & $0.475^{*}$ \\
& $(0.183)$ & $(0.183)$ & $(0.187)$ & $(0.227)$ & $(0.227)$ & $(0.227)$ \\
\hline$\Delta$ Free Trade & $0.062^{* *}$ & $0.062^{* *}$ & & $0.063^{* *}$ & $0.063 * *$ & \\
Agreement & $(0.018)$ & $(0.018)$ & & $(0.018)$ & $(0.018)$ & \\
\hline Free Trade Agreement & & & 0.004 & & & $0.019^{*}$ \\
& & & $(0.006)$ & & & $(0.009)$ \\
\hline$\Delta$ European Union & 0.001 & 0.001 & & -0.004 & -0.004 & \\
& $(0.024)$ & $(0.024)$ & & $(0.024)$ & $(0.024)$ & \\
\hline European Union & & & 0.011 & & & -0.002 \\
& & & $(0.008)$ & & & $(0.011)$ \\
\hline & & & & & & \\
\hline Country pair effects? & No & No & No & Yes & Yes & Yes \\
\hline Year effects? & Yes & Yes & Yes & Yes & Yes & Yes \\
\hline & & & & & & \\
\hline \# Obs. & 11,898 & 11,898 & 11,898 & 11,898 & 11,898 & 11,898 \\
\hline R ${ }^{2}$ & 0.24 & 0.24 & 0.24 & 0.24 & 0.24 & 0.44 \\
\hline
\end{tabular}

Notes:

Dependent variable is the change in the log of bilateral trade in real US dollars.

Robust standard errors are recorded in parentheses.

**,* and \# denote significant at the 1, 5 and 10 percent levels, respectively. 
b) European countries

\begin{tabular}{|l|l|l|l|l|l|l|}
\hline Sample & Europe & Europe & Europe & Europe & Europe & Europe \\
\hline Period & $1948-2003$ & $1948-2003$ & $1948-2003$ & $1948-2003$ & $1948-2003$ & $1948-2003$ \\
\hline & & & & & & \\
\hline$\Delta$ EMU2 & 0.048 & & & $\mathbf{0 . 0 2 7}$ & & \\
& $(0.030)$ & & & $(\mathbf{0 . 0 3 0})$ & & \\
\hline EMU2 & & 0.020 & 0.013 & & $\mathbf{- 0 . 0 0 1}$ & $\mathbf{- 0 . 0 0 3}$ \\
& & $(0.013)$ & $(0.014)$ & & $(\mathbf{0 . 0 1 4})$ & $(\mathbf{0 . 0 1 4})$ \\
\hline$\Delta$ Real GDP & 0.260 & 0.268 & 0.332 & 0.322 & 0.326 & 0.305 \\
& $(0.213)$ & $(0.213)$ & $(0.215)$ & $(0.234)$ & $(0.234)$ & $(0.234)$ \\
\hline$\Delta$ Real GDP per capita & 0.163 & 0.155 & 0.091 & 0.090 & 0.085 & 0.103 \\
& $(0.211)$ & $(0.211)$ & $(0.213)$ & $(0.232)$ & $(0.232)$ & $(0.232)$ \\
\hline$\Delta$ Free Trade & $0.068^{* *}$ & $0.062^{* *}$ & & $0.070^{* *}$ & $0.070^{* *}$ & \\
Agreement & $(0.016)$ & $(0.016)$ & & $(0.016)$ & $(0.016)$ & \\
\hline Free Trade Agreement & & & 0.006 & & & $0.021^{* *}$ \\
& & & $(0.006)$ & & & $(0.008)$ \\
\hline$\Delta$ European Union & 0.003 & 0.003 & & -0.004 & -0.004 & \\
& $(0.022)$ & $(0.022)$ & & $(0.022)$ & $(0.022)$ & \\
\hline European Union & & & $0.014 *$ & & & 0.000 \\
& & & $(0.006)$ & & & $(0.009)$ \\
\hline & & & & & & \\
\hline Country pair effects? & No & No & No & Yes & Yes & Yes \\
\hline Year effects? & Yes & Yes & Yes & Yes & Yes & Yes \\
\hline & & & & & & \\
\hline \# Obs. & 6,974 & 6,974 & 6,974 & 6,974 & 6,974 & 6,974 \\
\hline R & 0.31 & 0.31 & 0.31 & 0.32 & 0.32 & 0.32 \\
\hline
\end{tabular}

Notes:

Dependent variable is the change in the log of bilateral trade in real US dollars.

Robust standard errors are recorded in parentheses.

**,* and \# denote significant at the 1, 5 and 10 percent levels, respectively. 
Figure 5: Estimated EMU effects under different specifications - an overview

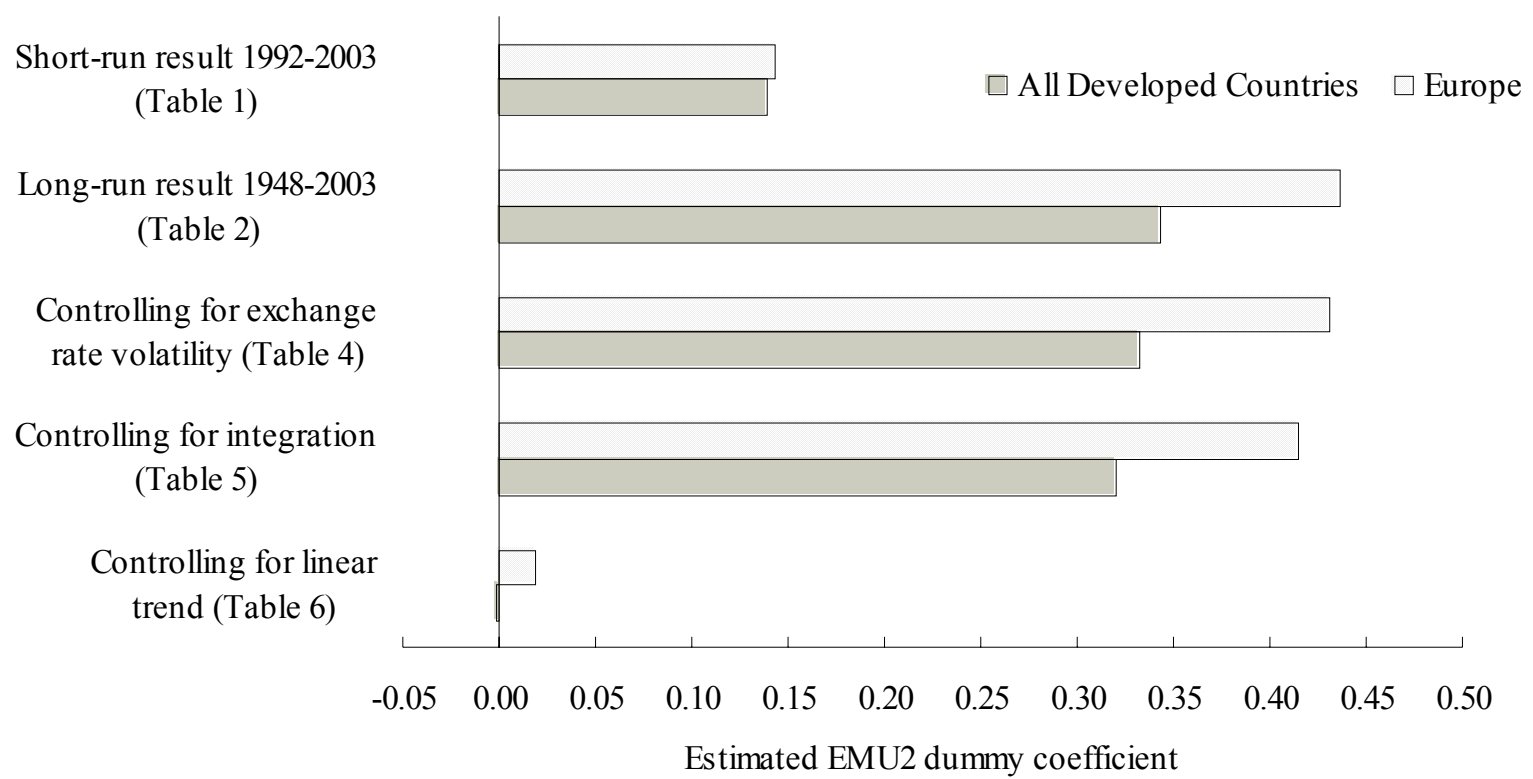

Notes: See the tables mentioned above. The EMU2 coefficients taken from Tables 4 and 5 have been re-scaled to match the long-run result of Table 2. 
These results are fairly robust. ${ }^{25}$ Alternative specifications of the trend variable leave the results basically unchanged. For instance, the EMU coefficient remains statistically indifferent from zero at conventional levels when we replace the linear trend by a quadratic trend. Results are shown in panel $\mathrm{b}$ of Table 6 . Table 7 presents the results of a firstdifference specification of the gravity model, examining the annual growth of trade. Again, the estimates support our initial (non-)result: we find that neither the coefficients for entry into the euro area $(\triangle \mathrm{EMU})$ nor EMU membership in general (EMU) are significantly different from zero. Allowing for country-pair specific (rather than EMU-specific) linear time trends also leaves the EMU effect statistically insignificant. Finally, the same holds, when we add a time-invariant constant to the linear trend variable for the EMU countries.

\section{$\underline{\text { Summary }}$}

Figure 5 summarizes the estimation results the standard regression approach and our key extensions discussed above. We conclude that the euro effect on trade, while more than a figment of the data, is perhaps best interpreted as the extension of a longer-term trend in European economic integration. There are indications that this trend, in part, reflects a number of measurable policy changes (at both the European and the unilateral level) aimed at fostering economic integration within Europe.

\section{Concluding Remarks}

Recent research suggests that the introduction of the euro has a sizable and statistically significant effect on trade among EMU members. Some estimates imply that EMU has increased trade by about 10 percent in its first four years of existence. This finding, if robust, has important policy implications for countries that are considering joining EMU.

In this paper, we put the adoption of the euro by EMU members in historical perspective. We argue that the creation of the EMU is best interpreted as a continuation, or culmination, of a series of policy changes that have led over the last five decades to greater economic integration among the countries that now constitute the EMU. Using a data set that includes 22 industrial countries from 1948 to 2003, we find strong evidence of a gradual

\footnotetext{
${ }^{25}$ All additional results not reported here are available on request.
} 
increase in trade intensity between European countries. Once we control for this trend in trade integration, the effect of the formation of the EMU disappears. A significant part of this trend can be explained by measures of economic integration preceding the introduction of the euro.

These results caution against an unqualified application of the Rose (2000) result that establishing a common currency significantly increases trade among union members to the case of the EMU. While it might well be true that - as some have argued - the advent of the euro was as necessary condition for the European integration process to continue beyond the "single market" agenda in the early 1990s, the euro's repercussions on trade are difficult to understand without taking proper account of the dynamics of the underlying European institutions. An obvious policy implication is that countries considering joining the euro area (or, for that matter, any currency union) should be wary regarding promises of an imminent acceleration of intra-area trade. 


\section{References}

Baldwin, Richard, Frauke Skudelny, and Daria Taglioni. 2005. "Trade Effects of the Euro: Evidence from Sectoral Data," ECB Working Paper 446.

Barr, David, Francis Breedon, and David Miles. 2003. "Life on the Outside: Economic Conditions and Prospects Outside Euroland," Economic Policy. 37 (October): 574-613.

Ben-David, Dan. 1993. "Equalizing Exchange: Trade Liberalization and Income Convergence” Quarterly Journal of Economics. 108 (August): 653-679.

Berger, Helge and Albrecht Ritschl. 1995. "Germany and the Political Economy of the Marshall Plan, 1947-52: A Re-Revisionist View" in Barry Eichengreen (ed.) Europe's PostWar Recovery. Cambridge: Cambridge University Press, 199-245.

Bun, Maurice and Franc Klaassen. 2002. "Has the Euro Increased Trade?" Tinbergen Institute Discussion Paper 02-108/2.

Bun, Maurice and Franc Klaassen. 2004. "The Euro Effect on Trade is not as Large as Commonly Thought,” Tinbergen Institute Discussion Paper 03-086/2.

De Nardis, Sergio and Claudio Vicarelli. 2003. "Currency Unions and Trade: The Special Case of EMU," Weltwirtschaftliches Archiv. 139 (4): 625-649.

De Sousa, José and Julie Lochard. 2004. "The Currency Union Effect on Trade and the FDI Channel," University of Paris 1.

Faruqee, Hamid. 2004. "Measuring the Trade Effects of the Euro," IMF Working Paper $04 / 154$

Flam, Harry and Håkan Nordström. 2003. "Trade Volume Effects of the Euro: Aggregate and Sector Estimates,” Mimeo, IIES Stockholm.

Glick, Reuven and Andrew K. Rose. 2002. "Does a Currency Union Affect Trade? The Time Series Evidence," European Economic Review. 46 (June): 1125-1151.

Gomes, Tamara, Chris Graham, John Helliwell, Takashi Kano, John Murray, and Larry Schembri. 2004. “The Euro and Trade: Is there a Positive Effect?" Mimeo, Bank of Canada.

Klein, Michael W. and Jay C. Shambaugh. 2004. "Fixed Exchange Rates and Trade," NBER Working Paper 10696.

Micco, Alejandro, Ernesto Stein and Guillermo Ordoñez. 2003. "The Currency Union Effect on Trade: Early Evidence from EMU,” Economic Policy. 37 (October): 315-356. 
Nitsch, Volker. 2005. "Currency Union Entries and Trade," in Jens Hölscher and Horst Tomann (eds.) Globalization of Capital Markets and Monetary Policy. Houndmills, Basingstoke: Palgrave Macmillan (forthcoming).

Persson, Torsten. 2001. "Currency Unions and Trade: How Large is the Treatment Effect?" Economic Policy. 33 (October): 435-448.

Rose, Andrew K. 2000. "One Money, One Market: The Effect of Common Currencies on Trade,” Economic Policy. 30 (April): 7-45.

Rose, Andrew K. 2004. "The Effect of Common Currencies on International Trade: A MetaAnalysis," in Volbert Alexander, Jacques Mélitz and George von Furstenberg (eds.) Monetary Unions and Hard Pegs. Oxford: Oxford University Press, 101-111. 


\section{$\underline{\text { Appendix }}$}

\section{A1. Data}

\section{a) Sources}

When compiling the data set, we aim to follow MSO as closely as possible. However, since we employ historical data reaching back to 1948, we sometimes had to use other sources. For instance, we often replace World Bank data (which are typically only available beginning in 1960) with IMF data. To make sure that data issues do not affect our results, we reestimated all our regressions with data from MSO's original sources (for shorter sample periods).

Our data set consists of annual observations for 22 industrialized countries between 1948 and 2003.

Trade. The trade data are taken in current US dollars from the International Monetary Fund's Direction of Trade Statistics. The nominal values are deflated by the US CPI.

GDP. GDP figures are derived in current local currency from the IMF's International Financial Statistics and converted into US dollars using current exchange rates (year averages). The nominal values are deflated by the US CPI.

Population. Population data are taken from the IMF's International Financial Statistics.

Distance. The distances are calculated as the Great Circle distance between the countries' geographic centers; the geographic coordinates are taken from the CIA World Factbook. Information for other gravity variables (common land border, common language) is also obtained from the CIA World Factbook.

FTA. The FTA dummy takes the value of one when the two countries in the pair belong to the same free trade area (FTA). The following FTAs are covered: Canada-US, ANZCER, EC, EFTA.

Exchange rates. The exchange rates are taken from the IMF's International Financial Statistics. 
b) Descriptive statistics

\begin{tabular}{|l|c|c|}
\hline & Non-EMU countries & EMU members \\
\hline Observations & 10,416 & 2,520 \\
\hline Trade & 1.071 & 1.853 \\
& $(2.241)$ & $(2.209)$ \\
\hline Real GDP & 14.601 & 14.723 \\
& $(2.637$ & $(2.135)$ \\
\hline Real GDP per capita & 9.606 & 9.169 \\
& $(1.292)$ & $(1.400)$ \\
\hline Distance & 8.241 & 7.052 \\
& $(1.112)$ & $(0.620)$ \\
\hline Common Language & 0.124 & 0.067 \\
& $(0.329)$ & $(0.249)$ \\
\hline Common Border & 0.054 & 0.222 \\
& $(0.226)$ & $(0.416)$ \\
\hline Free Trade Agreement & 0.188 & 0.442 \\
& $(0.390)$ & $(0.497)$ \\
\hline European Union & 0.083 & 0.402 \\
& $(0.276)$ & $(0.490)$ \\
\hline Landlocked & 0.177 & 0.200 \\
& $(0.356)$ & $(0.400)$ \\
\hline Island & 0.452 & 0.000 \\
& $(0.559)$ & $(0.000)$ \\
\hline Exchange rate volatility & 0.030 & 0.017 \\
& $(0.032)$ & $(0.026)$ \\
\hline Index of European integration & 6.719 & 17.726 \\
& $(8.924)$ & $(5.150)$ \\
\hline
\end{tabular}

The table reports means with standard deviations in parentheses. 
1951 Marshall plan institutions (i.e., the European Payments Union) help solve the German balance of payments crisis and, thus allow restitution of European division of labor; Treaty of Paris signed; European High Authority set up (to become EU Commission later).

1954 European Community of Coal and Steel comes into force (France, Germany, Italy, Belgium, Luxembourg, The Netherlands).

1957 Treaty of Rome establishes, among other things, the European Economic Community (EEC).

1960 European Free Trade Agreement (EFTA) is established (Austria, Denmark, Norway, Portugal, Sweden, Switzerland, UK).

1961 EFTA expansion: Finland

1962 Common Agricultural Policy is launched.

1965 European Community (EC): Merger of the three European "unions" (EEC, Coal \& steel, and Atomic Energy) in a treaty; single Council of Ministers and European Commission established to head the new institution.

1973 EC expansion: Denmark, Ireland, UK.

1974 EFTA expansion: Iceland

1979 First direct Europe-wide election to European Parliament; European Monetary System established.

1981 EC expansion: Greece

1986 EC expansion: Spain, Portugal.

1987 Single European Act comes into force, setting up "Single Market" framework and streamlines Commission's work.

1991 Maastricht Treaty establishes European Union (EU), sets up timetable for the Economic and Monetary Union (EMU), defines European citizenship, and initiates EU enlargement process.

1993 Single Market takes effect.

1995 EU expansion: Austria, Finland, Sweden; Schengen treaty takes effect (some countries).

1997 The Treaty of Amsterdam, among other things, updates Maastricht and further prepares eastward expansion.

1999 Euro introduced (physically in 2002). 


\section{CESifo Working Paper Series}

(for full list see www.cesifo.de)

1374 Sascha O. Becker, Karolina Ekholm, Robert Jäckle and Marc-Andreas Mündler, Location Choice and Employment Decisions: A Comparison of German and Swedish Multinationals, January 2005

1375 Christian Gollier, The Consumption-Based Determinants of the Term Structure of Discount Rates, January 2005

1376 Giovanni Di Bartolomeo, Jacob Engwerda, Joseph Plasmans, Bas van Aarle and Tomasz Michalak, Macroeconomic Stabilization Policies in the EMU: Spillovers, Asymmetries, and Institutions, January 2005

1377 Luis H. R. Alvarez and Erkki Koskela, Progressive Taxation and Irreversible Investment under Uncertainty, January 2005

1378 Theodore C. Bergstrom and John L. Hartman, Demographics and the Political Sustainability of Pay-as-you-go Social Security, January 2005

1379 Bruno S. Frey and Margit Osterloh, Yes, Managers Should Be Paid Like Bureaucrats, January 2005

1380 Oliver Hülsewig, Eric Mayer and Timo Wollmershäuser, Bank Loan Supply and Monetary Policy Transmission in Germany: An Assessment Based on Matching Impulse Responses, January 2005

1381 Alessandro Balestrino and Umberto Galmarini, On the Redistributive Properties of Presumptive Taxation, January 2005

1382 Christian Gollier, Optimal Illusions and Decisions under Risk, January 2005

1383 Daniel Mejía and Marc St-Pierre, Unequal Opportunities and Human Capital Formation, January 2005

1384 Luis H. R. Alvarez and Erkki Koskela, Optimal Harvesting under Resource Stock and Price Uncertainty, January 2005

1385 Ruslan Lukach, Peter M. Kort and Joseph Plasmans, Optimal R\&D Investment Strategies with Quantity Competition under the Threat of Superior Entry, January 2005

1386 Alfred Greiner, Uwe Koeller and Willi Semmler, Testing Sustainability of German Fiscal Policy. Evidence for the Period 1960 - 2003, January 2005

1387 Gebhard Kirchgässner and Tobias Schulz, Expected Closeness or Mobilisation: Why Do Voters Go to the Polls? Empirical Results for Switzerland, 1981 - 1999, January 2005 
1388 Emanuele Bacchiocchi and Alessandro Missale, Managing Debt Stability, January 2005

1389 Assar Lindbeck and Dirk Niepelt, Improving the SGP: Taxes and Delegation rather than Fines, January 2005

1390 James J. Heckman and Dimitriy V. Masterov, Skill Policies for Scotland, January 2005

1391 Emma Galli \& Fabio Padovano, Sustainability and Determinants of Italian Public Deficits before and after Maastricht, January 2005

1392 Angel de la Fuente and Juan Francisco Jimeno, The Private and Fiscal Returns to Schooling and the Effect of Public Policies on Private Incentives to Invest in Education: A General Framework and Some Results for the EU, January 2005

1393 Juan C. Conesa and Carlos Garriga, Optimal Response to a Demographic Shock, January 2005

1394 Christian Gollier, Optimal Portfolio Management for Individual Pension Plans, February 2005

1395 Ruslan Lukach, Joseph Plasmans and Peter M. Kort, Innovation Strategies in a Competitive Dynamic Setting, February 2005

1396 Gebhard Kirchgässner, (Why) Are Economists Different?, February 2005

1397 Marko Köthenbürger, Panu Poutvaara and Paola Profeta, Why are More Redistributive Social Security Systems Smaller? A Median Voter Approach, February 2005

1398 Gabrielle Demange, Free Choice of Unfunded Systems: A First Assessment, February 2005

1399 Carlos Fonseca Marinheiro, Sustainability of Portuguese Fiscal Policy in Historical Perspective, February 2005

1400 Roel M. W. J. Beetsma and Koen Vermeylen, The Effect of Monetary Unification on Public Debt and its Real Return, February 2005

1401 Frank Asche, Petter Osmundsen and Maria Sandsmark, Is It All Oil?, February 2005

1402 Giacomo Corneo, Media Capture in a Democracy: The Role of Wealth Concentration, February 2005

1403 A. Lans Bovenberg and Thijs Knaap, Ageing, Funded Pensions and the Dutch Economy, February 2005

1404 Thiess Büttner, The Incentive Effect of Fiscal Equalization Transfers on Tax Policy, February 2005

1405 Luisa Fuster, Ayşe İmrohoroğlu and Selahattin İmrohoroğlu, Personal Security Accounts and Mandatory Annuitization in a Dynastic Framework, February 2005 
1406 Peter Claeys, Policy Mix and Debt Sustainability: Evidence from Fiscal Policy Rules, February 2005

1407 James M. Malcomson, Supplier Discretion over Provision: Theory and an Application to Medical Care, February 2005

1408 Thorvaldur Gylfason, Interview with Assar Lindbeck, February 2005

1409 Christian Gollier, Some Aspects of the Economics of Catastrophe Risk Insurance, February 2005

1410 Gebhard Kirchgässner, The Weak Rationality Principle in Economics, February 2005

1411 Carlos José Fonseca Marinheiro, Has the Stability and Growth Pact Stabilised? Evidence from a Panel of 12 European Countries and Some Implications for the Reform of the Pact, February 2005

1412 Petter Osmundsen, Frank Asche, Bård Misund and Klaus Mohn, Valuation of International Oil Companies -The RoACE Era, February 2005

1413 Gil S. Epstein and Shmuel Nitzan, Lobbying and Compromise, February 2005

1414 Marcel F. M. Canoy, Jan C. van Ours and Frederick van der Ploeg, The Economics of Books, February 2005

1415 Eric A. Hanushek and Ludger Wößmann, Does Educational Tracking Affect Performance and Inequality? Differences-in-Differences Evidence across Countries, February 2005

1416 George Kapetanios and M. Hashem Pesaran, Alternative Approaches to Estimation and Inference in Large Multifactor Panels: Small Sample Results with an Application to Modelling of Asset Returns, February 2005

1417 Samuel Mühlemann, Jürg Schweri, Rainer Winkelmann and Stefan C. Wolter, A Structural Model of Demand for Apprentices. February 2005

1418 Giorgio Brunello and Lorenzo Rocco, Educational Standards in Private and Public Schools, February 2005

1419 Alex Bryson, Lorenzo Cappellari and Claudio Lucifora, Why so Unhappy? The Effects of Unionisation on Job Satisfaction, March 2005

1420 Annalisa Luporini, Relative Performance Evaluation in a Multi-Plant Firm, March 2005

1421 Giorgio Bellettini and Carlotta Berti Ceroni, When the Union Hurts the Workers: A Positive Analysis of Immigration Policy, March 2005

1422 Pieter Gautier, Michael Svarer and Coen Teulings, Marriage and the City, March 2005 
1423 Ingrid Ott and Stephen J. Turnovsky, Excludable and Non-Excludable Public Inputs: Consequences for Economic Growth, March 2005

1424 Frederick van der Ploeg, Back to Keynes?, March 2005

1425 Stephane Dees, Filippo di Mauro, M. Hashem Pesaran and L. Vanessa Smith, Exploring the International Linkages of the Euro Area: a Global VAR Analysis, March 2005

1426 Hans Pitlik, Friedrich Schneider and Harald Strotmann, Legislative Malapportionment and the Politicization of Germany's Intergovernmental Transfer System, March 2005

1427 Konstantinos Angelopoulos and Apostolis Philippopoulos, The Role of Government in Anti-Social Redistributive Activities, March 2005

1428 Ansgar Belke and Daniel Gros, Asymmetries in the Trans-Atlantic Monetary Policy Relationship: Does the ECB follow the Fed?, March 2005

1429 Sören Blomquist and Luca Micheletto, Optimal Redistributive Taxation when Government's and Agents' Preferences Differ, March 2005

1430 Olof Åslund and Peter Fredriksson, Ethnic Enclaves and Welfare Cultures - QuasiExperimental Evidence, March 2005

1431 Paul De Grauwe, Roberto Dieci and Marianna Grimaldi, Fundamental and NonFundamental Equilibria in the Foreign Exchange Market. A Behavioural Finance Framework, March 2005

1432 Peter Egger, Stefan Gruber, Mario Larch and Michael Pfaffermayr, Knowledge-Capital Meets New Economic Geography, March 2005

1433 George Economides and Apostolis Philippopoulos, Should Green Governments Give Priority to Environmental Policies over Growth-Enhancing Policies?, March 2005

1434 George W. Evans and Seppo Honkapohja, An Interview with Thomas J. Sargent, March 2005

1435 Helge Berger and Volker Nitsch, Zooming Out: The Trade Effect of the Euro in Historical Perspective, March 2005 